\title{
Belgelerden Hareketle Bir Restitüsyon Denemesi: Kayseri Karakolhaneleri
}

\author{
An Attempt at the Restitution of the Police Stations in Kayseri \\ with Reference to Archival Documentation
}

\begin{abstract}
Remzi AYDIN*
Öz: Kayseri, Anadolu'daki ticaret ve ulaşım yollarının kavşak noktasında yer alması bakımından tarihin hemen her devrinde önemli bir kent olmuştur. 19. yüzyıla gelindiğinde ticari hareketliliğini büyüterek sürdüren kentin nüfus artışına paralel, güvenlik ihtiyacı da çoğalmıştır. Aynı yüzyılda Osmanlı Devleti, büyük bir değişim ve dönüşüm sürecine girerek devlet kurumlarında yapısal reformlar gerçekleştirmiştir. Bunlardan bir tanesi de idari reformlardır. Bu kapsamda şehirlerin güvenliğinin sağlanmasındaki dağınık yapı ortadan kaldırılmış ve merkeziyetçi yapıya geçilmiştir. İlk olarak başkent İstanbul'da yürürlüğe konan reformlar, taşrada daha sonra başlamıştır. Bu çalışmada, bir taşra şehri olan Kayseri'de, idari reformlar sonucunda kurulan Emniyet Teşkilatı ve teşkilat mensuplarının görev yaptığı karakolhanelerin inşa süreci ortaya konulmuştur. Başbakanlık Osmanlı Arşivi’nde yaptığımız çalışmalarda, şehirde karakolhanelerin varlığı tespit edilmiştir. Yapılan kaynak taraması ve arazi çalışmasında bu karakolhanelerin günümüze ulaşmadığı, hatta araştırmacılar tarafından bilinmediği anlaşılmıştır. Arşiv belgelerinde karakolhanelere nerede, neden ihtiyaç duyulduğu, kaç personelin görev yapacağ gibi bilgilerin yanında, sosyo-ekonomik yapıya dair veriler de bulunmaktadır. Belgeler içerisindeki keşif ve rayiç defterleri ise bir karakolhanenin yapım sürecini açıkça anlatmaktadır. Defterlerdeki bilgilerden hareketle, Kayseri'de tip proje olarak inşa edilmesi planlanan karakolhanelerin restitüsyon çizimi ortaya çıkarılmıştır. Bu çizime göre karakolhanelerin, başkent İstanbul'dakiler ile kıyaslandığında işlevsel, küçük ve bezemesiz binalar olduğu anlaşılmıştır.
\end{abstract}

Anahtar sözcükler: Osmanlı, Emniyet Teşkilatı, Kayseri, Karakolhane, Arşiv Belgeleri

\begin{abstract}
Kayseri has been an important city throughout history, due to its location at a crossroads of trade and transportation. At the start of the $19^{\text {th }}$ century the need for public security increased in parallel with the city's population growth maintained to increase its commercial mobility. In the same century the Ottoman state conducted structural reforms in government institutions through entering into the process of change and conversion, with one of these reforms being the administrative reform. Within this context, the disorganised structure for providing security in the cities was abolished and a centralized structure was established. The reforms which were brought into force first in capital city, İstanbul, came into effect later in the provinces. In this study, the Law Enforcement Agency which was founded as a result of these administrative reforms and the course of building police stations in Kayseri, one of the provincial cities, is introduced. In consequence of research conducted at the Directorate of Ottoman Archives it was determined that there were police stations in Kayseri. At the end of the review of the literature and the field survey, it was clearly understood that these police stations had not survived to the present day and are even unknown to researchers. In the archive documents there is some data concerning the socio-economic structure in addition to information concerning where and why these police stations were needed and how many officers worked in them. The documents concerning the detailed estimate and the market price table clearly show the building process of these police stations. Based upon archive documentation the restitution plan has been drawn of the police stations planned to be constructed as a typical project in Kayseri. From this restitution plan it was understood that in comparison to those in İstanbul, the police stations of Kayseri were functional, small and undecorated buildings.
\end{abstract}

Keywords: Ottoman, Law Enforcement Agency, Kayseri, Police Stations, Archive Documents

\footnotetext{
* Yrd. Doç. Dr., Erciyes Üniversitesi, Edebiyat Fakültesi, Sanat Tarihi Bölümü, Kayseri. raydin@erciyes.edu.tr
} 
Güvenlik ve asayiş arayışı toplumsal yaşamın temel ihtiyaçlarından birisi olagelmiştir. Bu ihtiyaç, ülke dışından gelecek tehditlere karşı olabildiği gibi içerden gelecek tehditlere karşı da geliştirilen çeşitli savunma mekanizmalarıyla karşılanmaktadır. Dış tehditler sınırları korumakla görevli ordu tarafindan bertaraf edilirken içerideki güvenlik ve asayiş, tesis edilen farklı birimler vasıtasıyla halledilmeye çalışılmıştır.

Türkler tarihin eski devirlerinden itibaren iç güvenlik ve asayiş sorunlarını çözmek maksadıyla çeşitli kurumlar meydana getirmişlerdir (Türklerde iç güvenlik teşkilatlanmasının tarihi süreci hakkında detaylı bilgi için bk., Okçabol 1940; Tongur 1946; Alyot 1947; Tongur 1948; Kaynar 2002). Bu kurumlardan biri de karakol teşkilatıdır. "Karakol" veya "karagol" teriminin kökeni, ordunun çevresini korumakla görevli piyade ve süvari askerlerini tanımlayan "Karavul" sözcügünden gelmektedir (Özcan 2001, 430). Sonraki dönemlerde şehir güvenliğini sağlayan asker ve zabtiyelerin ikamet ettiği binalara "karavulhane", "karagolhane", "karakolhane" veya kısaltılmış haliyle "karakol" adı verilmiştir (Pakalın 1983, 200-201; Ergin 1995, 880-881). Osmanlı döneminde ise şehir içi güvenlik farklı dönemlerde çeşitli birimler tarafından sağlanmıştır. Bu birimler başkent İstanbul'da; Yeniçeri Ocağı, Cebeci Ocağı, Topçu Ocağı, Kaptanbaşılık ve Bostancıbaşılık şeklinde sıralanmaktaydı. Bu birimlerin görevlilerine kullukçu (sonraki dönemlerde kollukçu) adı verilmiştir (Özcan 2002, 1757-1758; Bilgiç \& Karakaya 2002, 174). Taşrada ise, subaşılar ve sipahiler güvenlikten sorumluydu (Fındıkl1 1999, 296-298). 1826 y1lında Yeniçeri Ocağı'nın kaldırılmasıyla iç güvenlik görevleri, yeni kurulan Asakir-i Mansure-i Muhammediye Ordusu ve destek kuvveti Redif Kumandanlıkları'na devredilmiştir (Toprak 1994, 457; Bilgiç \& Karakaya 2002, 176-177; Özcan 2002 1757-1758). 1844 yılında iç güvenliği sağlayan birimlerden Tımarlı Sipahi Örgütü ortadan kaldırılarak ülke çapında Zaptiye Teşkilatı tesis edilmesi kararlaştırılmıştır. İstanbul'un güvenliğini sağlamak için ise 1845 yılında Zabtiye Müşiriyeti kurulmuştur (Çadırcı 2013, 319). Böylelikle yetki ve faaliyet alanları birbirinden ayrışmış farklı birimlerde gerçekleştirilen güvenlik ve asayiş hizmetleri tek elden yürütülmeye, merkezileşmeye ve bürokratikleşmeye başlamıştır (Toprak 1994, 458; Özcan 2001, 431). 1846 yılından itibaren ülke sathında teşkilatlanmasını tamamlayan zaptiye, sonradan jandarma olarak adlandırılacak kolluk kuvvetini oluşturmuştur (Toprak 1986, 1269-1271). Zabtiye Müşiriyeti, 1879 yılında nezarete dönüştürülmüştür. 1881 yılında İstanbul'un asayişinden sorumlu Asakir-i Zabtiye Teşkilatı kaldırılmış (Bilgiç \& Karakaya 2002, 178) ve dört daireden müteşekkil İstanbul Polis Müdüriyeti adıyla yeni bir kolluk teşkilatı kurulmuş (Toprak 1994, 458; Özcan 2001, 431), aynı kurumlar 1885 yılından itibaren de taşrada tesis edilmiştir. 1894 yılına gelindiğinde 15 şehirde polis teşkilatı kurulmuştur (Bilgiç \& Karakaya 2002, 178; Yaşar 2008, 10). 1909 yılında Zabtiye Nezareti kaldırılmış, yerine Emniyet-i Umumiye Müdüriyeti adıyla Dâhiliye Nezareti'ne bağlı yeni teşkilat getirilmiştir (Birinci 1999, 14). Aynı yıl kurumsallaşma yolunda bir adım daha atılmış ve teşkilata personel yetiştirmek amacıyla Polis Okulu açılmıştır (Ali Birinci, ilk Polis Mektebi'nin 1891 yılında açıldığını, bir iradeye dayanarak, ifade etmektedir, Birinci 1999, 11). Bu teşkilatlanmanın başkent İstanbul'un ardından taşrada da benzer bir şekilde gerçekleştiği belirtilmektedir (Toprak 1994, 458; Doğan 1994, 277-278; Özcan 2001, 431).

Osmanlı iç güvenlik teşkilatlanması kısaca bu şekilde özetlenebilir. Polis teşkilatının kurulmasına vesile olan en önemli olay 1826 yılında Yeniçeri Ocağı'nın lağvıdır. Ardından 1839 y1lında ilan edilen Tanzimat Fermanı ve getirdiği reform sürecinden iç güvenlik teşkilatlanması da nasibini almıştır. Bu doğrultuda yukarıda belirtilen süreçte yeni kurumlar tesis edilmiştir. Osmanlı bürokratları, polis teşkilatının kurulmasında da diğer alanlarda olduğu gibi, Avrupa'da iç güvenlik hizmetlerinin nasıl sağlandığına dair araştırmalara girişmiştir. Araştırmalar neticesinde, Osmanlı toplumuna adapte edilebilecek en iyi sistemin genelde Fransız özelde ise, Paris 
Polis Teşkilatı'nın olduğuna karar verilmiştir. Bu doğrultuda 1880 yılından itibaren Fransa'dan yabancı uzmanlar getirtilerek, başkent İstanbul'da hizmet vermesi sağlanmıştır (Lévy 2006, 146-170). Teşkilatlanmadaki Fransız modelinin karakol binalarının tasarımına ne şekilde etki ettiğine dair herhangi bir bulgu, mevcut yayınlarda tespit edilememiştir. Anlaşılan o ki batılılaşma politikalarının yoğunlaşmasına paralel olarak güvenlik ve asayiş hizmetlerinin kurumsallaşması ve merkezileşmesi eğilimi de artmıştır. Böylece ulus devlete geçişin yapısal zemini de hazırlanmıştır.

Teşkilat mensuplarının görevlerini yerine getirdikleri mekânlar hakkındaki bilgilerimiz özellikle taşra için oldukça kısıtlıdır. Güvenliği sağlamakla yükümlü kolluk kuvvetleri, 19. yüzyıla gelinceye değin, başkent İstanbul'da bağlı bulundukları ocaklara ait bina ve kışlalarda ikamet etmekteydiler. 1826 yılına kadar İstanbul'un güvenliğini sağlayan yeniçeriler, kışlaların yanı sıra şehrin çeşitli yerlerinde bulunan kulluk (kolluk) veya karakulhane (karakolhane) (Şemseddin Sami, Kâmûs-ı Türkî' de karakolhane kelimesini "Muhafaza-i asayişe memur asker veya candarma (jandarma) bölüğü ikametine mahsus mahal" olarak tanımlamaktadır, Sami 2009, 1067) adı verilen binalarda görevlerini yapmaktaydılar. Aynı şekilde şehrin farklı bölgelerinin güvenliğinden sorumlu olan diğer birimlerin de kendilerine ait kullukları bulunmaktaydı (Toprak 1994, 457; Çiftçi 2001, 431; Özcan 2002, 1753-1758). Kullukların tesis edildiği yerler, genellikle esnafın ve ticari faaliyetin yoğun olduğu semtlerdir. Karakolhane adıyla bağımsız binaların yapılmasına ise 1831 y1lından itibaren başkent İstanbul'da başlanmıştır (Özcan 2001, 430-431). Ancak taşrada bağımsız karakol binalarının yapımına ne zaman başlanıldığı kesin olarak bilinmemektedir.

Bu çalışmada, Anadolu'nun merkezinde yer alan ve Osmanlı Dönemi'nde Ankara Vilayeti'ne bağlı önemli bir şehir olan Kayseri Sancağı'nda inşa edilmesi planlanan karakol binaları ele alınmıştır. Bugün şehirde tarihi nitelik taşıyan karakol binası maalesef bulunmadığından araştırmamızın veri kaynağını Başbakanlık Osmanlı Arşivi'nde bulunan konuyla ilgili belgeler oluşturmaktadır. Belgelerden bir kısmı karakol yapılarının ihtiyaçlarına ilişkin talepler ve cevaplarına, bir kısmı karakol olarak kullanılmak üzere tahsis edilmiş binaların kira bedellerinin ödenmesine, bir kısmı da yeni karakolların inşasına ilişkindir. Yeni karakolların inşasına ilişkin arşiv evrakları, dönemin inşa tekniği, inşada kullanılan malzemeler ve fiyatları, işçilik ücretleri ile plan özelliklerine dair bilgiler vermesi bakımından ayrıca önem taşımaktadır.

\section{Kayseri'de Polis Teşkilatı (Kolluk Kuvvetleri)}

Kayseri'de polis teşkilatının ne zaman kurulduğuna dair mevcut yayınlar ve incelenen belgelerde kesin bilgiler bulunmamaktadır. Buna paralel olarak ilk karakol binasının ne zaman, hangi semtte inşa edildiği de bilinmemektedir. Bununla birlikte Başbakanlık Osmanlı Arşivi’nde yer alan belgeler, Kayseri'deki polis teşkilatı ve binaları hakkında bazı bilgiler edinmemize imkân tanımaktadır. Arşiv tarama sisteminde "Kayseri" ve "polis" kelimeleri birlikte arandığında en erken tarihli belgenin 11 Ocak 1892 tarihli olduğu görülmektedir. Belgede, şehrin büyüklügü ve nüfusunun yoğunluğundan dolayı, bir komiser ile üç polisin istihdam edilmesine izin verildiği bildirilmektedir (BOA. DH. MKT. 1747/92). 1892 y1lına ait bu belgede güvenliği sağlamak üzere "polis" görevlendirilmesinden söz edilirken, bu tarihten 1911 yılına kadar olan diğer yazışmalarda zabtiye görevlendirmesinden bahsedilmektedir (1894-1911 yılları arasında şehrin güvenliğine ilişkin tüm yazışmalar, Seraskerlik Makamı ile Kayseri Sancağı'nın bağlı olduğu Ankara Vilayeti arasında gerçekleştirilmiştir. Belgelerin neredeyse tamamında Seraskerlik Makamı'na bağlı jandarma birimine mensup zabtiyelerin, şehrin güvenliğinden sorumlu olduğu bildirilmektedir).

Osmanlı geç dönem iç güvenlik hizmetlerinin Asakir-i Zabtiye tarafindan sağlandığından 
daha önce bahsetmiştik. İstanbul'da 1881 yılında kaldırılan bu birimin (Bilgiç \& Karakaya 2002, 178) yerine kolluk kuvveti olarak İstanbul Polis Müdüriyeti kurulmuştur (Toprak 1994, 458; Özcan 2001, 431). Polis müdürlüklerinin taşrada kurulması ise 1885 y1lından itibarendir (Bilgiç \& Karakaya 2002, 178; Yaşar 2008, 10). 1892 yılına ait belgede "polis" ibaresinin geçmesinden hareketle, Polis Müdüriyeti'nin Kayseri'de ilk olarak bu tarihte kurulduğu söylenebilir. 1894-1911 yılına kadarki yazışmalarda "jandarma" kelimesinin kullanılması ise bir geçiş süreci yaşandığını ve bu süreçte Seraskerlik'e bağlı askeri bir kuvvet olan jandarma bünyesindeki zabtiyelerin, Polis Müdüriyeti'nin teşkilatlanması tamamlanana kadar şehirde güvenliği sağladığ 1 şeklinde değerlendirilebilir. 1911 yılından itibaren yazışmalarda "polis" ibaresinin yoğunluk kazanmas1, Polis Müdüriyeti'nin bu tarih ile birlikte şehir içi güvenlik hizmetini tek başına yürüttüğünü göstermektedir. Polislerin olduğu gibi jandarmaya mensup zabtiyelerin de görevlerini icra ettikleri yapılara karakolhane denmektedir (Belgelerde ayrım gözetmeksizin polislerin ve zabtiyelerin görev yaptıkları binalardan karakol olarak söz edilmektedir).

\section{Belgelere Göre Karakolhaneler}

Şehir içi güvenliği sağlayan kolluk kuvvetleri kurumsal olarak döneme göre değişiklik gösterdiğinden, Kayseri'de inşa edilen veya inşası planlanan karakolları, jandarma ve polis karakolhaneleri olmak üzere iki grupta inceleyebiliriz.

\subsection{Jandarma Karakolhaneleri}

Kayseri'de mimari bir yapı olarak karakolhaneden söz edilmesine ilk olarak 25 Nisan 1894 tarihli belgede rastlamaktayız. Dâhiliye Nezareti tarafindan Seraskerlik Makamı'na ve Ankara Vilayeti'ne gönderilen bu belgede, şehrin Tekkeönü adlı bölgesinde bulunan ve mülkiyeti Masrar oğlu Markar adlı bir gayrimüslime ait kahvehanenin karakol olarak düzenlendiği ve 13 Ocak 1894'den (309 senesi Kanun-i Sanisi ibtidasından 310 senesi Temmuzu nihayetine) 12 Ağustos 1894 tarihine kadar 266 guruş bedelle kiralandığı, kiranın ise Seraskerlik tarafından ödeneceği yazılmıştır (BOA. DH. MKT. 229/58-2). Arşivde 1894-1904 yılları arasında konu ile ilgili herhangi bir yazışma mevcut değildir (Bahsi geçen tarihler arasında yazışma tespit edilememesi an itibariyledir. İlerleyen süreçte yeni belgelerin arşivde tasniflenmesi ile yeni belgeler ortaya çıkabilecektir).

Gerçek anlamda karakolhane yapımına yönelik ilk talep ise 1904 yılındadır. Kayseri Tensik (Nizam) Komisyonu 1 Ocak 1904 tarihinde, Seraskerlik Jandarma Dairesi'ne gönderdiği yazıda, 50000 nüfuslu şehirde yeterli sayıda zabtiye bulunmadığından asayişin sağlanamadığını belirtmektedir. Komisyon, sorunun çözümü için ise mevcut 12 kişilik piyade kuvvetine 20 kişinin daha ilavesine izin verilmesini ve münasib mahallere dört adet yeni karakolhane inşa edilmesini önermektedir (BOA. BEO. 2370/177713-1). 4 Temmuz 1904 tarihinde konu Jandarma Dairesi'nde görüşülerek isteklerin makul olduğu kanaatine varılmış, istihdamı istenen 20 kişilik piyadenin bütçede 34252 kuruşluk ek maliyet getireceği hesaplanarak durum, Serasker Rıza imzasıyla sadrazama bildirilmiştir (BOA. BEO. 2370/177713-2). 7 Temmuz 1904 tarihinde konu bu kez Bab-1 Ali Meclis-i Mahsus'da gündeme alınmış ve bu maliyetin bütçeye ilave edilemeyeceği, istihdama kesinlikle lüzum var ise bunun Ankara Vilayeti'ne bağlı liva ve kazalarda daha az jandarmaya ihtiyaç bulunan yerlerden tasarruf yapılarak sağlanması hususu karara bağlanmıştır (BOA. BEO. 2370/177713-3; BOA. MV. 109/81). 17 Temmuz 1904 tarihinde bu karar Seraskerlik makamına tebliğ edilmiştir (BOA. BEO. 2370/177713-4; BOA. MV. 109/81). 30 Ocak 1908 tarihli belgede, Kayseri'ye bağlı Talas Nahiyesi'nin doğusunda bir tepe üzerinde, üst katında dört oda, alt katında iki ahır bulunan harap bir Jandarma Karakolhanesi yer aldığı kaydedilmiştir. Talas sakinlerinden Kethüdazade Hacı Ahmet Efendi karakolhanenin nahiyenin d1şında kalmasından dolayı görevli personelin olaylara geç müdahalede bulunduğunu, bu sebeple 
nahiye merkezine yeni bir karakolhane yapılmasını, eskisinin ise inas (kız) mektebine dönüştürülmesi için Maarif Nezareti'ne dilekçe vermiştir (Özbek, 2011, 48-49; BOA. BEO. 3313/ 248422). Yaptığımız incelemede bu karakolhanenin günümüze ulaşamadığı tespit edilmiştir.

Şehirde günümüze ulaşmış Jandarma Karakolhanesi bulunmasa da günümüzde büyük oranda tahribata maruz kalmış Jandarma Mektebi adıyla bilinen bir bina bulunmaktadır. Bu binanın ilk olarak hangi maksatla inşa edildiği de bilinmemektedir. Fakat eski fotoğraflarda yapının önüne asılmış Osmanlıca levhada "Jandarma Mektebi" ibaresi okunmaktadır. İsminden hareketle yapının yakınlarında bir karakol binası olduğu söylenebilir.

\subsection{Polis Karakolhaneleri}

Arşiv belgelerinde kolluk kuvveti olarak polisten söz edilmesine 11 Eylül 1911 tarihinde Maliye Nezareti Emlak-1 Emiriyye Birinci Kalemi'nden çıkan yazıda rastlamaktayız. Bu belgeye göre 26 Temmuz 1911 tarihinde Ankara Vilayeti, Kayseri'de yapılması elzem olan bir adet yeni polis dairesinin inşası için 16.000 kuruşa ihtiyaç olduğunu belirterek gerekli meblağın harcanması için Maliye Nezareti'nden izin istemiştir. Maliye Nezareti bu talebi Emniyet-i Umumiye İdaresi'nin bağlı bulunduğu Dâhiliye Nezareti'ne havale etmiştir. 15 Ağustos 1911 tarihinde Dâhiliye Nezareti'nden gelen cevapta, Emniyet-i Umumiye Müdüriyeti'nin tamirat ve inşaata ayrılan bütçesinin sadece İstanbul karakolhanelerini kapsadığı gerekçe gösterilerek, vilayetlere bu bütçeden harcama yapılamayacağı belirtilmiştir. Maliye Nezareti, Ankara Vilayeti'ne inşa tahsisatının yapılabilmesi için Dâhiliye Nezareti'ne tekrar başvurulması gerektiğini ifade etmiştir (BOA. DH. EUM. MH. 244/57).

13 Mart 1912 tarihinde Kayseri Mutasarrıflı̆̆ı'ndan, Ankara Vilayeti'ne gönderilen yazıda, şehrin nüfusunun kalabalıklaştığı ve asayişin bozulduğu belirtilerek, uygun noktalarda (Bezirhan Önü, Keçikapu ve Dört Dükkân Önü namındaki mahaller) karakollar yapılması gerektiği bildirilmiştir. Karakolların birbirine ve merkeze İstanbul'dan sipariş edilen telefon tertibatı ile bağlanacağ 1 da belgede ifade edilmiştir. Yapılan keşif sonucu her biri 10.370 kuruş 61 santim olmak üzere, üç karakol için toplam 31.111 kuruş 81 santim paraya ihtiyaç olduğu tespit edilmiştir. Malzeme fiyatları ve işçilik ücretleri için rayiç defteri hazırlanmış, yapının haritası (plan) çizilmiş ve Ankara Vilayeti'ne bu eklerle birlikte gönderilerek gerekli işlemlerin yapılması talep edilmiştir (BOA. DH. EUM. MH. 245/24-4). Yazıya ek olarak gönderilen 14 Mart 1912 tarihli keşf-i evvel ve rayiç defteri, arşiv taramasında tespit edilmiş fakat bahsi geçen harita (plan-cephe çizimi) maalesef ilgili dosyadan çıkmamıştır. Ancak keşif defterinde yer alan bilgiler, yapının planına ilişkin veriler ortaya koymamıza imkân tanımaktadır. Bu noktada defterdeki bilgilerden hareketle yapının alternatifli restitüsyon çizimi (plan-cephe) ortaya çıarılmaya çalışılmıştır.

Defterin baş sayfasında üç mahal (Bezirhan Önü, Keçikapu ve Dört Dükkân Önü) isminin geçmesi ve maliyetlerin aynı oluşu, bu projenin üçüne de uygulanacağını göstermektedir. Başlık kısmı ile beraber üçer sayfadan ibaret olan keşf-i evvel ve rayiç defterindeki mühürde, Kayseriye Sancağı Nafia Kondüktörü (Pakalın tarafindan "Kondüktör" kelimesi, "Fen memuru" yerine kullanılır bir tabirdir. Nafia ve hassaten yol işlerinde kullanılan kondüktörler ilkin bu unvanla ameli şekilde yetişenlerden Nafia Nezaretince imtihanla tayin olunurlarken 9 Mayıs 1327 [1911] senesinde Nafia Nezareti tarafından açılan "Kondüktör Mektebi" mezunlarına hasredilmişti. Cumhuriyet devrinde Kondüktör Mektebi "Teknik Okul" adını almış ve mezunlarına "Fen Memuru" denilmiştir" şeklinde tanımlanmıştır, Pakalın 2004, 292) Mehmed Talat bin Emin yazılıdır. Keşif defterindeki bilgilerde yapının inşası için öncelikli olarak 8.90x4.50 m ölçülerinde, $1 \mathrm{~m}$ derinliğe sahip bir alanda hafriyat yapılacağı belirtilmektedir. Bu alan içerisinde yine aynı ölçülerde olmak üzere $1 \mathrm{~m}$ genişlik ve yükseklikte temel duvarlarının inşa edileceği ifade edilmiştir. Alanı çevreleyen temel duvarlarının iç kısmında; bir adet boyuna-uzunlamasına (tulani) 2 
m'lik, iki adet de enine-genişliğine (arzani) 4.5 m'lik bölme duvarının olacağı anlaşılmaktadır. Temel kazısının ardından bodrum katın inşasına ilişkin bilgiler yer almaktadır. Bu bilgilere göre bodrum kat, temel duvarları üzerinde $0.75 \mathrm{~m}$ kalınlıktaki duvarlarıyla $2 \mathrm{~m}$ olarak yine aynı yönde uzanan bölme duvarları ile yükselecektir. Bodrum kat duvarları üzerine, $0.75 \times 0.75 \mathrm{~m}$ ölçülerinde, yedi adet demir parmaklıklı pencere yerleştirilmesi planlanmıştır. Defterdeki veriler mekânın planını çıkarmamıza olanak verecek derecededir. Dört cephe beden duvarlarının ölçülerinden $(4.50 \times 8.90 \mathrm{~m})$ binanın dikdörtgen bir formda olduğu anlaşılmaktadır. Bu ölçülerin d1şındaki verilerimiz, iki adet enine-genişliğine uzanan 4.50, bir adet de boyuna-uzunlamasına yönelen 2 m'lik bölme duvarıdır. Enine uzanan duvarların binayı üçe böleceği açıktır. Ancak 2 m'lik bölme duvarı nereye yerleştirileceği kesin olarak bilinmemektedir. Çıkarımlarımıza göre bu duvar dikdörtgen alanın ortasında yer alarak mekânların iki yönde eşit olarak bölünmesini sağlamıştır. Böylelikle ortadaki alan ikiye bölünmüş ve toplamda dört adet hacim meydana getirilmiştir. Bodrum katın fonksiyonuna dair bilgi yer almamakla birlikte, pencerelerinin demir parmaklıklı olarak tasarlanması burasının nezarethane olabileceğini düşündürmektedir. Defterde bodrum kattaki mekânların kapısına dair herhangi bir bilgi bulunmamaktadır (Metinde belirtilen sebeplerden dolayı bodrum katın restitüsyon çiziminde gösterilen kapı açıklıklarının yeri ve genişliği izafidir). Defterde bodrum kat ifadesinin geçmesi, cephe çizimi yapılırken dikkate alınmıştır. Bu çerçevede $0.75 \mathrm{~m}$ yüksekliğindeki pencerenin alt ve üstünden $0.25 \mathrm{~m}$ boşluk bırakılmış geriye kalan 0.75 m'lik kısım zemin kotundan aşağıda bırakılmıştır. Bu da bodrum katın zemin kotundan 1.25 m yukarıda olduğunu ve üst kata merdiven kullanılarak ulaşılacağını göstermektedir. Defterde merdivene dair herhangi bir bilginin bulunmaması çizimini yapmamıza engel teşkil etmiştir. Bodrum kat için verilen ölçüler, duvar kalınlıkları değişmekle birlikte, üst katla (fevkani) tamamen aynıdır. Bu da katların birbiriyle aynı planda yapıldığını göstermektedir. Defterde üst kat beden duvarlarının $0.40 \mathrm{~m}$, bölme duvarlarının ise $0.30 \mathrm{~m}$ kalınlığında, $4 \mathrm{~m}$ olarak yükseleceği kaydedilmiştir. Duvar kalınlığı ve yüksekliğinin dışında, bodrum kattan farklılaşan diğer unsurlar kapı ve pencere sayılarıdır. Defterde yazılanlara göre üst katta, her biri $1 \mathrm{~m}$ genişliğinde ve $2 \mathrm{~m}$ yüksekliğinde üç iç (dâhili) ve $1.5 \mathrm{~m}$ genişliğinde ve $2.4 \mathrm{~m}$ yüksekliğinde bir dış (harici) olmak üzere toplam dört kapı kullanılacaktır. Ayrıca beden duvarlarında her biri $1 \mathrm{~m}$ genişliğinde ve $2 \mathrm{~m}$ yüksekliğinde dokuz pencere yer alacaktır. $1 \mathrm{~m}$ genişliğinde ve $1.5 \mathrm{~m}$ yüksekliğindeki pencerenin ise kapı üzerine yerleştirileceği yazılıdır. Ancak kapı ve üzerindeki pencerenin yükseklik ölçüleri toplanıp $(3.9 \mathrm{~m})$ cephenin yüksekliği $(4 \mathrm{~m})$ ile oranlandığında $0.10 \mathrm{~m}$ gibi bir boşluk kalmaktadır ki bu cephede orantısız bir görünüme sebep olmaktadır. Muhtemelen kapı üzerinde yer alan pencerenin genişlik ve yükseklik ölçüleri defterde yanlış sütunlara yazılmıştır. Bu durumda pencerenin genişliğinin $1.5 \mathrm{~m}$, yüksekliğinin ise $1 \mathrm{~m}$ olması gereklidir. Pencere genişliğinin $1.5 \mathrm{~m}$ olması, kapının genişliği $(1.5 \mathrm{~m})$ ile de uyum sağlamakta ve orantısızlığı ortadan kaldırmaktadır. İç kapı sayılarının (3 adet) defterde belirtilmiş olması, birinci kattaki bölümlenme hakkında fikir yürütmeye olanak sağlayan en önemli veridir. Buna göre üst katta biri ortak, üçü bağımsız olmak üzere toplamda dört mekân bulunacaktır. Dış kapıdan geçildikten sonra salon olarak adlandırdığımız mekâna ulaşılır. Salon, biri tam karşıda, ikisi ise her iki yanda olmak üzere üç adet odaya geçit vermektedir. Yanlardaki dikdörtgen planlı odalar, birbiri ile simetrik olup, iki cephelerinde birer, bir cephelerinde ise ikişerden dörder pencere ile aydınlatılmaktadır. Karşıdaki dikdörtgen oda da ise bir pencere yer almaktadır. Fonksiyona ilişkin bilgiler bulunmamaktadır. Salonun karşısındaki diğerlerinden küçük boyuttaki odanın karakolda görevli komiser veya komiser muavinlerine, yanlardaki odaların ise memurlara tahsis edildiği ileri sürülebilir. Binanın iki cephesinde tavan seviyesinin üzerinde $0.30 \mathrm{~m}$ genişliğinde, $0.50 \mathrm{~m}$ yüksekliğinde ve $8.90 \mathrm{~m}$ uzunluğunda çelen duvarı (Defterde bu duvara "sakf iki cephe duvarı" denilmektedir. İstanbul'daki örnekler için Aynur Çiftçi, "parapet duvarı" veya "atika duvarı" terimlerini kullanmaktadır, Çiftçi 1996, 127) inşa edileceği defterde yer alan bil- 
gilerdendir. Çatı muhtemelen bu duvarların arkasında gizlenerek kurulacaktır. Böylelikle cepheye daha yüksek ve hareketli bir görünüm kazandırılacaktır. Defterde bina çatısının, tavanının ve zemin döşemesinin $9.5 \times 6.5 \mathrm{~m}$ ölçülerinde ahşaptan yapılacağ 1 bildirilmekle birlikte, tavan ve zemin ölçülerinden 5 m'lik duvar kalınlığı düşülerek hesaplama yapılmıştır. Binaya bir de helâ yapılacağ1 defterde bildirilen bir başka husustur (BOA. DH. EUM. MH. 245/24-3). Ancak helânın binanın neresinde olacağı, binaya dâhil mi yoksa hariç mi olarak yapılacağı anlaşılamamıştır (Tablo 1, Fig. 1-3). İstanbul karakollarında helâların yapının içinde veya dışında, binaya bitişik olarak yapılmış örnekleri mevcuttur (Çiftçi 1996). Restitüsyon çiziminin yapılmasında esas alınan prensip, simetri olmuştur (Aynur Çiftçi'nin İstanbul karakollarına ait orijinal çizimlerini de kullandığ 1 çalışmasından, planlamada simetrinin esas alındığı görülmektedir. Alidost Ertuğrul 19. yüzyılda karakolların yanı sıra yeni ortaya çıkan diğer yapı tiplerinin planlanmasında da simetrik kurgunun esas alınan unsurlardan biri olduğunu belirtmektedir, Çiftçi 1996; Ertuğrul 2009, 303-304). Mekânların boyut ve sayıları, pencere ve kapıların yerleştirilmesi, bu ilke doğrultusunda yapılmıştır (Restitüsyon çiziminin yapılmasında, defterde yer alan binanın beden duvarları, bölme duvarları, çelen duvarı, pencere ve kapı gibi unsurlarının ölçüleri esas alınmıştır. Binanın hangi doğrultuda inşa edileceği bilgisi bulunmadığından çizimde yön belirtilmemiştir. Pencere ve kapıların yerleri de bilinmemektedir. Bu sebeple pencere ve kapı açıklıklarının yerleştirilmesinde, İstanbul'daki mevcut karakol örneklerine ve eski fotoğraf-çizimlere bakılarak, cephe ve planlarda simetrik bir düzen olduğu tespit edilmiş ve çizimde benimsenmiştir. Çatının çizilmesinde de aynı yöntem izlenmiştir. Bu noktada Aynur Çiftçi'nin çalışmasında yer alan çizim ve fotoğraflardan faydalanılmıştır. Bu fotoğrafların büyük bir kısmı II. Abdülhamid Han'ın Yıldız Albümü'nden, geri kalan kısmı ise, muhtelif koleksiyonlardandır, Çiftçi 1996). Tüm bu verilerden hareketle restitüsyon çizimi ortaya çıkmıştır (Fig. 1).

Rayic defteri de yapının inşasına yönelik önemli bilgiler sunmaktadır. Defterin ilk kısmında amele, usta ve taşçı esnafının yevmiye miktarları ile nakliye bedeli belirtilmiştir. Buna göre amele 5, taşç1 9, usta ise 12 kuruş günlük ücret karşılı̆̆ında çalışmaktadır. Defterin devamında ise inşaatta yapılacak işlerin detaylı olarak metreküp bedelleri kaleme alınmıştır. Metreküp başına birim fiyat; temel kazısı (hafriyat) için 1.20, harçlı temel duvarı inşası için (taşların 2 km.'den nakli, kırılma bedeli, harç için kireç ve kum ücreti, usta ve amele yevmiyesi ile aletedevat masrafı ve müteahhit kârı dahil olmak üzere) 45, harçlı duvar inşası için (taşların 2 km.'den nakli, kırılma bedeli, harç için kireç ve kum ücreti, usta ve amele yevmiyesi ile aletedevat masrafı ve müteahhit kârı dahil olmak üzere) 47.05, yonu duvarı inşası için (20 adet taş bedeli, taşın nakliyesi, taşın yontulması ve yerleştirilmesi, harç için kireç ücreti ile alet-edevat ve müteahhit kârı dahil olmak üzere) 64.80, ahşap çatı için (ölçüleri belirlenmiş ahşap malzeme bedeli, amele ve usta yevmiyesi, oluklu galvanizem (sac) ile alet-edevat ve müteahhit kârı dahil olmak üzere) 43.98, tavan-taban döşemesi için 24, kapı için 15 ve pencere için 10 kuruş olarak hesaplanmıştır (BOA. DH. EUM. MH. 245/24-3). Kullanılan malzeme ve birim maliyetin yanı sıra rayiç defterinden süsleme ve tekniğe dair bilgilere de ulaşmaktayız. Binanın üzerini kapatacak tavan için "silmeli ve şemsiyeli" ifadesinin kullanılması, tavan kenarlarının silmeli, merkezinin ise göbekli olarak yapılacağı şeklinde yorumlanabilir. Benzer şekilde zemin döşemesi için "lambalı" ifadesinin kullanılması, tahtaların kenarlarındaki "oyuk ve kinişlerle" (Hasol 1979, 325) birbirine geçirildiğini göstermektedir. Osmanlı geç dönem mimarisinde bina cephelerinin köşelerinde kullanılan taşların kısmen dışarı taşırılarak plastik bir etki sağlandığı görülmektedir. Rayiç defterinde köşe taşlarının yonu taşından yapılacağının belirtilmesi cephede benzer bir uygulamanın yapılacağı şeklinde değerlendirilebilir (Tablo 2, Fig. 4-6). 

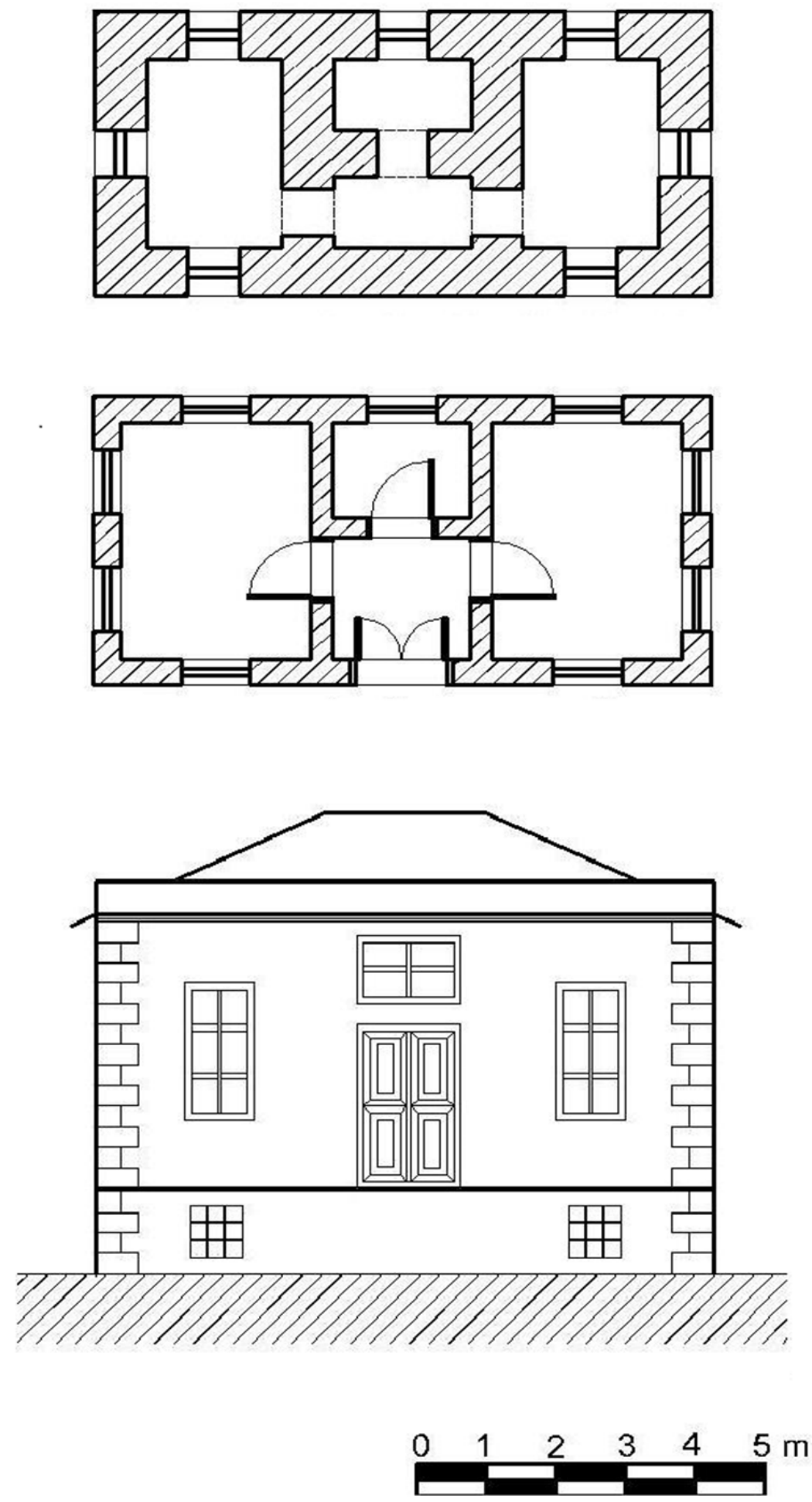

Fig. 1. Bodrum Kat, Üst Kat ve Cephe Görünüşü Restitüsyonu

Kayseri Mutasarrıflığı'nın karakolhane inşasına yönelik talebini, Ankara Valisi yerinde bulmuş ve 25 Mart 1912 tarihinde Dâhiliye nezareti'ne iletmiştir (BOA. DH. EUM. MH. 245/24-1). 26 Mart 1912 tarihinde Kayseri Mutasarrıfı Cemal tarafından çekilen telgrafta, inşa edilecek karakolhanede polislerin ikame ettirileceği Ankara Valiliği'ne bildirilmiştir (BOA. DH. EUM. MH. 
245/24-2). Ankara Valiliği'nin talebi 2 Nisan 1912 tarihinde Emniyet-i Umumiye Müdüriyeti'ne havale edilerek 4 Nisan 1912'de aynı müdüriyetin muhasebe şubesinden görüş istenmiştir. Muhasebe 15 Nisan 1912 tarihli derkenarda, Emniyet-i Umumiye Müdüriyeti'ne inşaat için ayrılan toplam bütçenin 120.000 kuruş olduğunu, dolayısıyla talep edilen 30.900 kuruşun bu bütçeden kullanılmasının uygun olmayacağını, bu gibi taleplerin bütçe görüşmeleri sırasında maliye meclisinde dile getirilmesi gerektiğini belirtmiştir (BOA. DH. EUM. MH. 245/24-1a).

19 Ocak 1913 tarihinde Dâhiliye Nezareti'nden emniyet-i Umumiye Müdüriyeti'ne gönderilen yazıda, Kayseri'nin 12.000 hane ve 3.000'e yakın dükkâna sahip, 56.000 nüfusluk geniş bir şehir olduğu, şehir ahalisinin "klz oynatmak ve havaya silah slkmak" gibi gayr-i ahlaki ve kanuni fiiller işlenmesi dolayısıyla mevcut polis sayısı ile bunun önüne geçilemediği ifade edilmiştir. Bu olayların önlenebilmesi için şehrin Selaldı, Çifteönü, Deliklitaş ve Tekkeönü adlı mahallelerinde altışar polis, birer muavinden oluşan dört karakolhane yapılmasının gerekliliği vurgulanmıştır (BOA. DH. EUM. MEM. 123/48-2). 24 Ocak 1913 tarihli belge, yırtılmış olduğundan yazıya ne cevap verildiği anlaşılamamıştır (BOA. DH. EUM. MEM. 123/48-1).

17 Haziran 1913'te Emniyet-i Umumiye Müdüriyeti'nden Dâhiliye Nezareti'ne gönderilen yazıdan, Kayseri'de yeni polis istihdamı ile birkaç karakolhane tesisine ihtiyaç duyulduğu anlaşılmaktadır. Aynı yazıdan karakolhane ihtiyacının inşa yerine, kiralama yöntemi ile giderileceği tespit edilmektedir. Üç karakolhane için senelik 3.200 kuruş kira bedeli belirlenmiş, bu miktarın dokuz aylık 2.400 kuruşu ise bütçeden tahsis edilmiştir (BOA. DH. EUM. 60/10-1, 2).

Ankara Valisi tarafından Dâhiliye Nezareti'ne gönderilen 1 Şubat 1914 tarihli yazıdan Kayseri'de iki karakol inşa edildiği anlaşılmaktadır (BOA. DH. EUM. MH. 76/55-1, 3). Merkez Memuru tarafindan 5 Eylül 1914 tarihinde Emniyet-i Umumiye Müdüriyeti'ne gönderilen telgraftan, Kayseri' de kiralık olarak kullanılan üç karakol olduğu ve bunlar için 190 kuruş ödendiği öğrenilmektedir (BOA. DH. EUM. MH. 88/83-1).

26 Ekim 1915 tarihli Kayseri Polis Merkez Kumandanlı̆̆ı'ndan Emniyet-i Umumiye Müdüriyeti'ne gönderilen yazı, kiralık olarak kullanılan Keçikapu ve Cafer Beğ karakollarının daha az kira ödenmesi amacıyla mevcut yerlerinden başka bir yere naklolunduğuna dairdir. Yazıda, diğer iki karakol gibi kira olan Gülük Karakolu'nun da İstanbul Caddesi üzerinde, inşası tamamlanmak üzere olan İstanbul Kapusu Karaklolu'na nakledileceği dile getirilmiştir (BOA. DH. EUM. MH. 111/95). 13 Haziran 1916'da Emniyet-i Umumiye Müdüriyeti'nden Kayseri Polis Müdürlüğ̈̈’ne gönderilen telgrafta, karakol olmak üzere kiralanan binaların değeri ve y1llık kiraları sorulmuştur (BOA. DH. EUM. MH. 138/116-1). 13 Haziran ve 5 Temmuz 1916 tarihlerinde gönderilen cevapta, Kiçikapu Karakolu'nun 100, Bahçebaş1 Karakolu'nun ise 80 lira değerinde olduğu belirtilmiştir. Senelik kira olarak ise birincisine 800, ikincisine 500 kuruş ödendiği yazılmıştır (BOA. DH. EUM. MH. 138/116-2, 3). 25 Ocak 1917 tarihli belge, Kayseri Polis İdaresi'ne ait binanın tamiri için keresteci esnafından alınan ağaç ve tahtaların parasının ödenmesine ilişkindir (BOA. DH. EUM. MH. 147/7).

Kayseri Polis Merkez Memurluğu'ndan, Emniyet-i Umumiye Müdürü'ne gönderilen 24 Mart 1917 tarihli yazıdan, Develi kazası ile Talas Nahiyesi’nde birer karakol binası yer aldığı öğrenilmektedir (BOA. DH. EUM. MH. 152/52-1, 2). Her iki ilçede de günümüze ulaşmış tarihi karakol binası mevcut değildir. 23 Ekim 1917 ve 21 Aralık 1917 tarihli iki belge, karakolhane olmak üzere kiralanmış binaların kira bedellerinin ödenmesine ilişkin Maliye, Dâhiliye ve Kayseri Mutasarrıflığı arasındaki yazışmaları içermektedir (BOA. DH. EUM. MH. 167/9-1, 2).

Kayseri Polis Merkez Kumandanlığı'ndan, Emniyet-i Umumiye Müdüriyeti'ne gönderilen 8 Aralık 1917 tarihli yazı, şehir ve ilçelerindeki karakolhane sayısını bildirmesi bakımından önemlidir. Buna göre şehirde, iki kaza ve bir nahiye ile merkezde dört olmak üzere toplam yedi 
polis karakolhanesi bulunmaktadır (BOA. DH. EUM. MH. 259/13). Belgelerden yedi karakolhaneden altısının yeri tespit edilebilmektedir. Bunlar; Develi Kazası Karakolu, Talas Nahiyesi Karakolu, Keçikapı Karakolu, Bağçebaşı Karakolu, Gülük Karakolu ve İstanbul Kapısı Karakolu şeklinde sıralanmaktadır. Bunlardan sadece İstanbul Kapısı Karakolhanesi'nin inşa yoluyla (BOA. DH. EUM. MH. 111/95), diğerlerinin ise (Keçikapı, Bağçebaşı ve Gülük karakolhaneleri BOA. DH. EUM. MH. 138/116-3, Belgede Keçikapı Karakolu'nun Bolatyan Arakil'e, Bağçebaşı Karakolu'nun ise Tataryan Dikran'a ait metruk binalar olduğu yazılıdır) mevcut binaların kiralanarak dönüştürülmesi ile karakolhane yapıldığını öğrenmekteyiz. Mevcut konutların karakola dönüştürülerek kullanılması İstanbul'da da görülmektedir (Çiftçi 1996, 117). Şehirde yer alan polis karakolları ile ilgili son yazışma 31 Aralık 1917 tarihli olup, jandarma ve polis karakollarının gaz yağı ihtiyacına ilişkindir (BOA. DH. İ.UM. 20/2).

Arşiv belgeleri şehirdeki karakol binalarının sayısı, yeri, mülkiyet durumu ve mimarisine ilişkin yukarıda bahsedilen bilgileri sunmaktadır. Bu bilgilerden hareketle, keşif ve rayiç defterinde adı geçen üç mahalden ikisinde (Bezirhan Önü ve Keçikapu) kesin olarak karakol yapım işinin gerçekleştirilmediğini söyleyebiliriz. Kayseri'de karakolhane olarak kullanılmak üzere inşa edilen tek yapı, belgelerde adı geçen İstanbul Kapısı Karakolhanesi'dir. Bu yapının da yeri tam olarak bilinmemektedir. Bununla birlikte, üzerinde yapıldı̆̆ 1 belirtilen İstanbul Caddesi'nin, kapalı çarşının meydan girişinden başlayıp, (günümüzdeki adı Park Bulvarı) Dört Dükkân Önü'ne (bugünkü adıyla Düvenönü), oradan da batıya yönelerek (günümüzdeki Osman Kavuncu Bulvarı) devam eden bir yol olduğu, 1927 yılına ait Kayseri haritasından anlaşılmaktadır (Eravşar 2013, 117, Bu harita, Mehmet Çayırdağ Arşivi'nde bulunmaktadır). Keşif ve rayiç defterlerinde karakolhanelerden bir tanesinin Dört Dükkân Önü, bugünkü adıyla Düvenönü'nde inşa edileceği yazılıdır. Bu iki veri birlikte değerlendirildiğinde keşif ve rayiç defterinde adı geçen Dört Dükkân Önü Karakolhanesi'nin yine aynı yerde İstanbul Kapısı Karakolu adıyla inşa edildiği ileri sürülebilir. Bunu destekler verilerden ilki inşaatın gerçekleştirildiği mahal, ikincisi ise İstanbul Kapısı Karakolhanesi'nin yapımına ilişkin doğrudan herhangi bir yazışmanın bulunmamasidir.

\section{Değerlendirme}

Çalışmanın bu bölümünde, şehirde günümüze ulaşmış bir karakolhanenin bulunmayışından dolayı, arşiv belgelerinden elde edilen veriler ve bu verilerden hareketle yapılan restitüsyon çizimlerine bağlı olarak değerlendirmelerde bulunulacaktır. Bu anlamda yine mevcut yayınlar çerçevesinde, diğer şehirlerde bulunan karakol binaları ile de karşılaştırmalar yapılacaktır.

\subsection{Malzeme ve Teknik}

Keşif ve rayiç defterinden anlaşıldığına göre karakolhanelerin inşasında temel olarak iki malzeme kullanılmaktadır. Bu malzemelerden taş, yapının beden ve bölme duvarlarında, ahşap ise tavan, çatı, döşeme, kapı ve pencerelerde kullanılmaktadır. Rayiç defterinde, taşın işlenme durumuna göre iki türünün kullanıldığını görmekteyiz. Bunlardan ilkini beden duvarları için duvar taşı, ikincisini ise köşe duvarları için yonu taşı oluşturmaktadır. Yapıdaki beden ve bölme duvarları, kapatıcı ve bölücü işlevinin yanı sıra taşıyıcı bir fonksiyon da üstlenmiştir. Zemin döşemesinde kullanılan ahşap malzemenin silmeli ve lambalı olacağı belirtilirken tavanın silmeli ve şemsiyeli olarak yapılacağı rayiç defterinde ifade edilmiştir. Silmeli ifadesi, zemin döşemesi ve tavanın kenarlarına pervazlar çakılacağını, lambalı ifadesi ise tahtaların geçmeli olduğunu göstermektedir. Şemsiyeli ifadesi ise tavanda bir göbek uygulaması yapılacağını düşündürmektedir. Kap1 ve pencerelerde kullanılacak ahşabın niteliği defterlerde belirtilmemiştir (Cephe görünüşünde dış kapı üzerine işlenen süslemeler dönem kapılarının genelinde görülmektedir). 
Metal malzeme, pencere parmaklıklarında, kapı-pencere takımlarında (menteşe, kilit, zenberek, halka) ve ahşap birleştirmesinde çivi (mismar) olarak kullanılmıştır. İnşada kullanılan bir başka malzeme ise harçtır. Rayiç defterinde belirtildiğine göre kullanılacak olan harcın bileşiğinde çalı kireci ve kum yer almaktadır. Harcın içeriğindeki oranlamaya bakıldığında iki kum, bir kireç olduğu görülmektedir.

Genel olarak bakıldığında karakolhanelerin inşası için hazırlanan malzemelerin hemen hemen tüm yapı türlerinde görülen zaruri unsurlar olduğu görülmektedir.

\subsection{Plan Özellikleri}

Kayseri'de günümüze ulaşan herhangi bir karakol binası bulunmadığından plan özelliklerinin yerinde tespiti mümkün olmamıştır. Arşiv belgelerinde, geçen "resm" ifadesi karakolların planlarının yapım öncesi bir tasarım aşamasından geçirilerek çizildiğini göstermektedir. $\mathrm{Bu}$ doğrultuda, keşif ve rayiç defterinden hareketle ortaya koyduğumuz plan ve cephe çizimlerine göre yapı bodrum ve üst olmak üzere iki kattan meydana gelmektedir. Bodrum kat ile üst kat aynı plan özelliklerine sahiptir. Plana etki eden hususlardan bir tanesi de taşıyıcı sistemdir. Keşif defterindeki temelden başlayarak duvar kalınlıklarının yukarı çıkıldıkça küçülmesi, kat duvarlarının birbiri üzerinde yükseldiğini göstermektedir. Ayrıca duvarlar dışında herhangi bir taşıyıc1 (sütun, direk, ayak) unsurdan bahsedilmemesi bu öngörümüzü destekler niteliktedir. Taşıyıcı sistem açısından bakıldığında bu tasarım gayet tabii ve normal bir durumdur. Yapıda üç oda ve bir sofa olmak üzere dört mekân yer almaktadır. Boyut olarak bakıldığında karakolun yaklaşı $40 \mathrm{~m}^{2}$ 'lik küçük bir binadan ibaret olduğu görülmektedir. Plan olarak değerlendirildiğinde, konut mimarisinde gördügümüz ortadaki salonun veya sofanın etrafında sıralanmış hacimlerden meydana geldiği anlaşılmaktadır. Karakolda istihdam edilecek personel sayısı, arşiv belgelerinde, bir komiser muavini ile altı polis olmak üzere toplamda yedidir (BOA. DH. EUM. MEM. 123/48-2). 8 Mayıs 1913 tarihli Polis Nizamnamesi'nde de benzer şekilde karakolda ikisi binada, dördü devriyede olmak üzere altı nefer (polis) ile bir komutan (komiser) olmak üzere yedi personelin görev başında olması gerektiği ifade edilmiştir (Alyot 1947, 526; Çiftçi 1996, 135-136). Emniyet-i Umumiye kayıtlarına göre 1915 yılında Kayseri'de bir merkez memuru, bir ser-komiser, iki ikinci komiser, dört komiser muavini ve 36 polis olmak üzere toplam 44 personel görev yapmaktadır (Tanışık 2009, 65). Bu bilgi nizamnamede belirtilen madde ile uygunluk göstermektedir. Ayrıca daha önce belirttiğimiz karakol sayıları ile de uyum sağlamaktadır. $\mathrm{Bu}$ veriler dikkate alındığında, restitüsyon çizimi yapılan binanın ölçüleri ile içerisindeki birimlerin ikamet açısından yeterli olduğu tespit edilmektedir.

Karakol binaları ile ilgili olarak maalesef az sayıda yayın bulunmaktadır. Bu yayınların büyük çoğunluğu, Osmanlı başkenti İstanbul'daki karakollar hakkındadır. Karakolların mimarisi hakkında bilgi veren en önemli kaynaklardan ilki, yine bir arşiv belgesidir. $\mathrm{Bu}$ belgede İstanbul'da inşa edilecek karakolların şimdiye kadar ahşaptan olduğu, bundan sonra yapılacak karakolların ise kargir olarak yapılması istenmektedir (Ergin 1995, 880-881). Osmanlı döneminde belirli bir plan ve mimari anlayışta karakol binalarının yapılmasına 1831 yılından itibaren başlanmıştır. Bundan önce yapılmış ve günümüze ulaşamayan karakollar ise ihtiyaca cevap verebilecek şekilde ahşaptan konut mimarisi geleneğinde inşa edilmiş binalardır (Arslan 1999, 75). İstanbul'da inşa edilen karakol binalarının genel olarak bodrum üzerine bir veya iki kat olarak, kare veya dikdörtgen planda yapıldıkları belirtilmektedir (Çiftçi 1996, 124). Bu plandaki karakol binalarında giriş holüne açılan odalar yer almaktadır. Binaların boyutlarının ise yapıldıkları bölgenin nüfus yoğunluğuna göre değiştiği ifade edilmektedir (Arslan 1999, 76-84; Sevin 2002, 395-399). İstanbul'un dışındaki karakollar ile ilgili tek yayın Bursa karakollarıdır. Bursa'daki karakollardan da maalesef günümüze sadece eski fotoğraflar ulaşmıştır. Plan 
özellikleri tespit edilemese de karakolların tuğla veya taş malzemeden kargir olarak, bodrum üzerine tek veya iki katlı olarak bina edildiği eski fotoğraflardan anlaşılmaktadır. Bodrum pencerelerinin demir parmaklıklı oluşu bu kısımların nezarethane olabileceğini işaret etmektedir (Yavaş 2003, 71-79). İstanbul'daki tarihi karakollardan birçoğu sadece fotoğraflarda yaşamaktadır. Bu karakollardan malzeme, cephe ve form bakımından, restitüsyon çizimini yaptığımız karakol ile benzerlik taşıyan örnekleri; Baruthane Merkez Karakolu, Harbiye Karakolu, Bahçe Karakolu, İcadiye Karakolu, Altunizade Karakolu, Ayazma Karakolu, Çengelköy Karakolu, Kuzguncuk Karakolu, Paşalimanı Karakolu, Şemsipaşa Karakolu, Bostancı (Bostancıbaş1) Karakolu, Modaburnu Karakolu, Kızıltoprak Karakolu, Sahra-yı Cedid Karakolu, Haydarpaşa Karakolu (Çiftçi 1996, 139, 145, 196, 200, 213-215, 222-227, 231-235, 257-261, 266-279, 282292, 304, 306, 307, 310, 316-317) ve Otakçılar Karakolu (Çiftçi 1998, 233-235) şeklinde sıralayabiliriz. İsmini sıraladığımız örneklerden Şemsipaşa Karakolu, kat durumu (bodrum+üst kat), malzemesi, dikdörtgen planı (15,5x5,50 m. ölçülerinde), pencere oranı $(1 / 2)$ ve atika duvarı (parapet duvarı) gibi özelikleriyle restitüsyon çizimini yaptığımız Kayseri'deki karakol ile en yakın özelliğe sahip olandır (Çiftçi 1996, 282-292). Diğer örneklerde ise bodrum kat bulunmamaktadır.

\subsection{Süsleme}

Keşif ve rayiç defteri yapının oldukça sade yapılacağını ortaya koymaktadır. Süsleme unsuru sayılabilecek unsurlardan biri cephenin köşelerinde kullanılacak yonu taşlarının dışa taşırılmasıyla elde edilecek estetik görünüştür. Bir diğer unsur ise göbek olarak değerlendirebileceğimiz "silmeli şemsiyeli tavan"dır. Bahsettiğimiz bu unsurların kesinliği bulunmayıp faraziyedir.

\section{Sonuç}

Devletlerin ve toplumların devamı için asayişin sağlanması birincil önceliktir. Osmanlı devleti kuruluşundan itibaren, ister merkezde isterse taşrada olsun, asayişin sağlanmasına büyük önem vermiştir. Geniş bir coğrafyada yüzyıllarca hüküm süren Osmanlı devleti, 19. yüzyılda hemen her alanda hızlı bir değişim ve dönüşüm geçirmiştir. Dünyada yaşanan askeri, siyasi, ekonomik ve toplumsal gelişmeler, bu dönüşümü gerekli ve zorunlu kılmıştır. Tanzimat ve Islahat fermanları bu gelişmelerin bir sonucu olarak ilan edilmiştir. Devlet aslında zaten var olan can, mal, irz ve vicdan özgürlüğünü ayrım gözetmeksizin garantiye aldığını bu fermanlarla beyan etmiştir. $\mathrm{Bu}$ doğrultuda idareciler, farklı alanlarda yeni çözümler üretmeye yönelik adımlar atmışlardır. Bunlardan bir tanesi de, kent reformları kapsamında, şehir içi güvenlik hizmetlerindeki değişimlerdir. Devlet daha önce bu görevi ülkenin genel güvenliğinden sorumlu ordu mensubu askeri kuvvetle sağlarken, dönüşüm sürecinde iç işlerine bağl1 yeni bir kolluk kuvveti oluşturarak sağlamıştır. Bu yeni kuvvetin adı Polis Müdüriyeti'dir. Önceleri başkent İstanbul'da faaliyete geçirilen bu kurum, ilerleyen yıllarda tüm ülke sathına yayılmıştır.

Belgelerden anlaşıldığı kadarıyla, Kayseri'de 1892 yılında Polis Müdüriyeti kurulmuş, ancak teşkilatlanmasını 1911 yılından sonra tamamlamış ve tam anlamıyla hizmete başlamıştır. Polis, devletin güç ve otoritesini kullanarak kamu düzenini sağlamakla yükümlüdür. Görevlerini yaptıkları karakol binaları bu bakımdan resmi bir kimlik taşımakta olup, devlet gücünün ve otoritesinin temsilidir. İstanbul'daki örneklere (büyüklük, konum ve estetiklik açılarından) bakıldığında bu temsiliyetin binalarla somutlaştığı açıkça fark edilebilir.

Taşrada inşa edilen karakolların, başkente nispetle daha küçük ve sade olduğunu restitüsyon çizimini yaptığımız örnekten anlamaktayız. Tip proje olarak üç mahalde inşası düşünülen karakolların ihtiyaca cevap verebilecek şekilde küçük ebatlı olduğu ortaya çıkmıştır. Yapıların ebatları ile çalışacak personel sayısının doğru orantılı olduğu da tespit edilmiştir. Belgelerde yer alan bilgiler yapıların sade ve bezemesiz olarak tasarlandığını göstermektedir. Karakolların inşa 
edileceği mahallere (Bezirhan Önü, Keçikapu, Dört Dükkân Önü) bakıldığında, şehri kuşatan dış kale surlarının da dışında olduğu anlaşılmaktadır. Bezirhan Önü ve Keçikapu mahalleri 19. yüzyılda asayiş olaylarının yoğun olarak yaşandığı ve ağıllı̆ıını gayrimüslimlerin teşkil ettiği mahallelerdir. İnşa edildiğini düşündügümüz İstanbul Kapısı Karakolu'na konum olarak bakıldığında hem şehrin giriş ve çıkış noktasında, hem de ticari yapıların (Dört Dükkân ÖnüDüvenönü) bulunduğu bir yerdedir. Yapıların inşa edileceği yerlerin seçiminde; toplumsal yapı, ekonomik hareketlilik, nüfus yoğunluğu ve asayiş durumu gibi hususların göz önünde bulundurulduğu belgelerde ifade edilmiştir. Şehrin büyüklüğü, nüfusunun çokluğu ve ticari hacmi "Kayseri kasabası tahminen on iki bin (12000) hane ve üç bine (3000) karib dekandan mürekkeb ve elli altı bin (56000) nüfusu şamil vasi' bir memleket olub" sözleriyle, asayiş olaylar1 ise "ahali-yi mahalliye ise kaz oynatmak ve hevaya silah atmak gibi adetle me'luf olmalarına nazaran" cümleleriyle dile getirilmiştir.

Netice olarak bu çalışmada, Kayseri'de günümüze ulaşamayan ve varlığı bilinmeyen bir yapı tespit edilmiştir. Plan ve cephe özellikleri ise arşiv vesikalarındaki bilgilerin elverdiği oranda ortaya çıkarılmaya çalışılmıştır. Bunun yanı sıra bir yapının inşa süreci de belgeler vasıtasıyla açığa çıkarılmış, dönem içerisinde kullanılan malzeme, uygulanan teknik, inşada görev alan esnaf ve maliyetin unsurları tespit edilen diğer bulgulardır. Başkent İstanbul'da yeni bir yapı tipi olarak 19. yüzyılda ortaya çıkan karakol binalarının Kayseri’ye gelişi 20. yüzyılın başlarını bulmuştur. Zaman farkıyla olsa da değişim ve dönüşümün taşraya yansıdığı, Kayseri'deki karakol binalarının yapım sürecinden anlaşılmaktadır. 
Tablo 1. Keşf-i Evvel Defteri Transkripsiyonu (BOA. DH. EUM. MH. 245/24-3)

\begin{tabular}{|c|c|c|c|c|c|c|c|c|c|}
\hline \multirow{2}{*}{$\begin{array}{l}\text { İnşaatın } \\
\text { Beyanı }\end{array}$} & \multirow{2}{*}{$\begin{array}{l}\text { Aksam-1 } \\
\text { teşabüh }\end{array}$} & \multicolumn{3}{|c|}{ Ebadı } & \multirow{2}{*}{$\begin{array}{l}\text { Metre mika'b } \\
\text { veya } \\
\text { murabba'1 }\end{array}$} & \multirow{2}{*}{$\begin{array}{l}\text { Beherinin } \\
\text { Fiyatı }\end{array}$} & \multicolumn{2}{|c|}{ Sarfiyat } & \multirow{2}{*}{$\begin{array}{l}\text { Mülahaz } \\
\text { at }\end{array}$} \\
\hline & & Tul & Arz & İrtifa'1 & & & Yekün & İcmali & \\
\hline \multicolumn{10}{|l|}{$\begin{array}{l}\text { (1)Temel } \\
\text { hafriyatı }\end{array}$} \\
\hline $\begin{array}{l}\text { Tulani } \\
\text { beden } \\
\text { duvarlar1 }\end{array}$ & 2 & 8,9 & 1 & 1 & 17,8 & & & & \\
\hline $\begin{array}{l}\text { Arzani } \\
\text { beden } \\
\text { duvarlar1 }\end{array}$ & 2 & 4,5 & 1 & 1 & 9 & & & & \\
\hline $\begin{array}{l}\text { Tulani } \\
\text { derun } \\
\text { bölmeleri }\end{array}$ & 1 & 2 & 1 & 1 & 2 & & & & \\
\hline $\begin{array}{l}\text { Arzani } \\
\text { derun } \\
\text { bölmeleri }\end{array}$ & 2 & 4,5 & 1 & 1 & 9 & & & & \\
\hline Yekün & & & & & 37,8 & 1,2 & 45,36 & & \\
\hline \multicolumn{10}{|l|}{$\begin{array}{l}\text { (2)Harçlı } \\
\text { inşaat }\end{array}$} \\
\hline $\begin{array}{l}\text { Tulani } \\
\text { beden } \\
\text { duvarlar1 }\end{array}$ & 2 & 8,9 & 0,8 & 2 & 26,7 & & \multirow{2}{*}{\multicolumn{3}{|c|}{$\begin{array}{l}\text { Harç iki kum bir kireçle } \\
\text { memzuc bulunacakdır. }\end{array}$}} \\
\hline $\begin{array}{l}\text { Arzani } \\
\text { beden } \\
\text { duvarları }\end{array}$ & 2 & 4,5 & 0,8 & 2 & 13,5 & & & & \\
\hline $\begin{array}{l}\text { Tulani } \\
\text { derun } \\
\text { bölmesi }\end{array}$ & 1 & 2 & 0,8 & 2 & 3 & & \multirow{2}{*}{\multicolumn{3}{|c|}{$\begin{array}{l}\text { İşbu inşaatta bodrum kat } \\
\text { da dahildir. }\end{array}$}} \\
\hline $\begin{array}{l}\text { Arzani } \\
\text { derun } \\
\text { bölmesi }\end{array}$ & 2 & 4,5 & 0,8 & 2 & 13,5 & & & & \\
\hline Yekün & & & & & 56,75 & & & & \\
\hline $\begin{array}{l}\text { Tulani } \\
\text { beden } \\
\text { duvarlar1 }\end{array}$ & 2 & 8,9 & 0,4 & 4 & 28,4 & & & & \\
\hline $\begin{array}{l}\text { Arzani } \\
\text { beden } \\
\text { duvarları }\end{array}$ & 2 & 4,5 & 0,4 & 4 & 14,4 & & & & \\
\hline $\begin{array}{l}\text { Tulani } \\
\text { beden } \\
\text { duvarlar1 }\end{array}$ & 1 & 2 & 0,3 & 4 & 2,4 & & & & \\
\hline $\begin{array}{l}\text { Arzani } \\
\text { beden } \\
\text { duvarlar1 }\end{array}$ & 2 & 4,5 & 0,3 & 4 & 10,8 & & & & \\
\hline $\begin{array}{l}\text { Sakf iki } \\
\text { cihet cephe } \\
\text { duvarı }\end{array}$ & 2 & 8,9 & 0,3 & 0,5 & 2,67 & & & & \\
\hline Yekün & & & & & 118,17 & & & & \\
\hline
\end{tabular}




\begin{tabular}{|c|c|c|c|c|c|c|c|c|c|}
\hline \multirow[t]{2}{*}{\begin{tabular}{|l|} 
Pencere ve \\
kap1 \\
boşluğu \\
minha \\
\end{tabular}} & & & & & 29,62 & \multirow[b]{2}{*}{45} & \multirow[b]{2}{*}{3984,75} & & \\
\hline & & & & & 88,45 & & & & \\
\hline $\begin{array}{l}\text { (3)Ahşab } \\
\text { sakf inşası }\end{array}$ & 1 & 9,5 & 6,5 & $\div$ & $\begin{array}{c}\text { Terbian } \\
61,75\end{array}$ & TJ & 2817 & & \\
\hline $\begin{array}{l}\text { (4)Ahşab } \\
\text { tavan }\end{array}$ & 1 & 9,5 & 6,5 & $\div$ & 61,75 & & & & \\
\hline $\begin{array}{l}\text { Duvar } \\
\text { kalınlığ }\end{array}$ & & & & & 5 & & & & \\
\hline & & & & & 56,75 & & & & \\
\hline $\begin{array}{l}\text { Aynı } \\
\text { ebadda } \\
\text { döșeme }\end{array}$ & & & & & \multicolumn{2}{|l|}{56,75} & & & \\
\hline & & & & & 113,5 & 24 & 2724 & & \\
\hline $\begin{array}{l}\text { (5)Dahili } \\
\text { sıva inşası }\end{array}$ & 0 & $\div$ & 21 & 4 & 82,8 & & & & \\
\hline \multirow[t]{2}{*}{$\begin{array}{l}\text { Kap1 ve } \\
\text { pencere } \\
\text { boşluğu } \\
\text { minha }\end{array}$} & & & & & \multirow[t]{2}{*}{29,72} & & & & \\
\hline & & & & & & 5 & 26,9 & 9832 & \\
\hline \multirow{3}{*}{$\begin{array}{l}\text { İnşaatın } \\
\text { Beyanı }\end{array}$} & \multirow{3}{*}{$\begin{array}{l}\text { Aksam-1 } \\
\text { teşabüh }\end{array}$} & \multicolumn{3}{|c|}{ Ebadı } & \multirow{2}{*}{$\begin{array}{c}\text { Metre } \\
\text { mika'b } \\
\text { veya } \\
\text { murabba'1 }\end{array}$} & \multirow[b]{2}{*}{$\begin{array}{c}\text { Beherinin } \\
\text { Fiyatı }\end{array}$} & \multicolumn{2}{|c|}{ Sarfiyat } & Mülahazat \\
\hline & & Tul & Arz & İrtifa'1 & & & Yekün & İcmali & \\
\hline & & & & & & & 9832,01 & & $\begin{array}{l}\text { Nakli } \\
\text { yekün }\end{array}$ \\
\hline $\begin{array}{l}\text { Fevkani } \\
\text { harici kapı }\end{array}$ & 1 & $\div$ & 1,5 & 2,4 & 3 & & & & \\
\hline \multirow[t]{2}{*}{$\begin{array}{l}\text { Fevkani } \\
\text { dahili kapı }\end{array}$} & 3 & $\div$ & 1 & 2 & 6 & & & & \\
\hline & & & & & 9 & 15 & 135 & & \\
\hline $\begin{array}{l}\text { Fevkani } \\
\text { pencere } \\
\text { çerçeveleri }\end{array}$ & 9 & $\div$ & 1 & 2 & 18 & & & & \\
\hline $\begin{array}{l}\text { Bodrum } \\
\text { pencere } \\
\text { çerçeveleri }\end{array}$ & 7 & $\div$ & 0,8 & 0,75 & 0,56 & & & & \\
\hline $\begin{array}{l}\text { Kap1 üzeri } \\
\text { penceresi }\end{array}$ & 1 & $\div$ & 1 & 1,5 & 1,5 & & & & \\
\hline Yekün & & & & 20,6 & 20,06 & 10 & 200,6 & & \\
\hline $\begin{array}{l}\text { Beheri üç } \\
\text { kıyye } \\
\text { olmak } \\
\text { üzere }\end{array}$ & & & & & Aded fi & & & & \\
\hline $\begin{array}{l}\text { Bodrum } \\
\text { pencereleri } \\
\text { demir } \\
\text { parmaklığg } 1\end{array}$ & & & & & $7 X 3=21$ & 3 & 63 & & \\
\hline $\begin{array}{l}\text { Ma } \\
\text { müsstemilat } \\
\text { hela inşasi }\end{array}$ & & & & & & & 150 & & \\
\hline & & & & & & & & 10371 & \\
\hline
\end{tabular}


Tablo 2. Rayiç Defteri Transkripsiyonu (BOA. DH. EUM. MH. 245/24-3)

\begin{tabular}{|c|c|c|c|}
\hline \multicolumn{2}{|c|}{ Adi amele yevmiyesi } & \multicolumn{2}{|c|}{5,00} \\
\hline \multicolumn{2}{|l|}{ Usta yevmiyesi } & \multicolumn{2}{|c|}{12} \\
\hline \multicolumn{2}{|l|}{ Taşçı yevmiyesi } & \multicolumn{2}{|c|}{9} \\
\hline \multicolumn{2}{|l|}{ Öküz arabası } & \multicolumn{2}{|c|}{15} \\
\hline \multicolumn{2}{|c|}{ Levazımatın Envai ve Müfredatı } & \multicolumn{2}{|c|}{ Esmanı } \\
\hline & & Guruş & Yekün \\
\hline \multirow{5}{*}{$\begin{array}{l}\text { Bir metro mika'b } \\
\text { türab hafriyatı }\end{array}$} & Hafriyat içün $2 / 15$ amele yevmiyesi & 0,66 & \\
\hline & $\begin{array}{l}\text { Üç metro mesafeye kürekle atılması 1/15 amele } \\
\text { yevmiyesi }\end{array}$ & 0,33 & \\
\hline & & 0,99 & \\
\hline & Alet ve edavat mesarifiyle müteahhid karı & 0,19 & \\
\hline & Yekün & & 1,20 \\
\hline \multirow{8}{*}{$\begin{array}{l}\text { Bir metro mika’b } \\
\text { harçli temel duvar } \\
\text { inşas1 }\end{array}$} & $\begin{array}{l}\text { Bir metro mika’b duvar taşının iki kilometrodan öküz } \\
\text { arabasıyla nakli }\end{array}$ & 6,00 & \\
\hline & Kırılması içün bir amele yevmiyesi & 5,00 & \\
\hline & $\begin{array}{l}\text { Bir metro mika'b temel duvarına on batman çalı kireç } \\
\text { beher batman iki guruş }\end{array}$ & 20,00 & \\
\hline & Bir metro mika'b kum yirmi batman & 1,00 & \\
\hline & $\begin{array}{l}\text { Bir metro mika'b temel duvarına } 1 / 4 \text { usta yevmiyesi ve } \\
2 / 4 \text { amele yevmiyesi }\end{array}$ & 5,50 & \\
\hline & & 37,50 & \\
\hline & Alet ve edevat mesarifiyle müteahhid karı & 7,50 & \\
\hline & Yekün & & 45,00 \\
\hline \multirow{8}{*}{$\begin{array}{l}\text { Bir metro mika'b } \\
\text { harçlı duvar inşası }\end{array}$} & $\begin{array}{l}\text { Bir metro mika’b duvar taşının iki kilometrodan öküz } \\
\text { arabasıyla nakli }\end{array}$ & 6,00 & \\
\hline & Kırılması içün bir amele yevmiyesi & 5,00 & \\
\hline & $\begin{array}{l}\text { Bir metro mika'b duvar içün on batman çalı kireci } \\
\text { beher batman iki guruş }\end{array}$ & 20,00 & \\
\hline & Bir metro mika'b kum yirmi batman & 1,00 & \\
\hline & $\begin{array}{l}\text { Bir metro mika'b duvara } 2 / 3 \text { usta yevmiyesi ve } 2 / 3 \\
\text { amele yevmiyesi }\end{array}$ & 7,25 & \\
\hline & & 39,25 & \\
\hline & Alet ve edevat mesarifiyle müteahhid karı & 7,80 & \\
\hline & Yekün & & 47,05 \\
\hline \multirow{7}{*}{$\begin{array}{l}\text { Bir metro mika'b } \\
\text { yonu duvarı inşası }\end{array}$} & $\begin{array}{l}\text { Bir metro mika'b köşe duvarlarına yirmi aded yonu taş } \\
\text { beheri fi } 0,50\end{array}$ & 10,00 & \\
\hline & $\begin{array}{l}\text { Bir metro mika'b köşe duvarlarına yirmi aded yonu taş } \\
\text { nakli }\end{array}$ & 10,00 & \\
\hline & $\begin{array}{l}\text { Bir metro mika'b köşe duvarlarına yirmi aded yonu taş } \\
\text { yonulması ve yerine vazı' }\end{array}$ & 20,00 & \\
\hline & $\begin{array}{l}\text { Bir metro mika'b içün yedi batman çalı kireci beher } \\
\text { batman iki guruşdur }\end{array}$ & 14,00 & \\
\hline & & 54,00 & \\
\hline & Alet ve edevat mesarifiyle müteahhid karı & 10,80 & \\
\hline & Yekün & & 64,80 \\
\hline \multirow{2}{*}{\multicolumn{2}{|c|}{ Levazımatın Envai ve Müfredatı }} & \multicolumn{2}{|c|}{ Esmanı } \\
\hline & & Guruş & Yekün \\
\hline Bir metro mika'b & On santimetro arzında on beş santimetro amikinde & 4 & \\
\hline
\end{tabular}




\begin{tabular}{|c|c|c|c|}
\hline \multirow[t]{9}{*}{ sakf inşası } & mahyalarına her iki metro tulünde bir makas kiriș & & \\
\hline & $\begin{array}{l}0,10 \text { arzında } 0,15 \text { amikinde arzının her iki metro tulünde } \\
\text { bir aded tulani kiriş }\end{array}$ & 5 & \\
\hline & $\begin{array}{l}0,06 \text { arzında } 0,12 \text { amikinde } 0,60 \text { santimetroda bir çember } \\
\text { taban keşidesiyle } 1 \text { zkara bedeli }\end{array}$ & 7 & \\
\hline & Üstadiye içün $1 / 5$ amele ve usta yevmiyesi & 3,4 & \\
\hline & Yarım kıyye kargıcı itmanı & 1,25 & \\
\hline & Oluklu galvanizem bedeli & 16 & \\
\hline & & 36,65 & \\
\hline & Alet ve edavat mesarifiyle müteahhid karı & 8,33 & \\
\hline & Yekün & & 43,98 \\
\hline \multirow{5}{*}{$\begin{array}{l}\text { Bir metro } \\
\text { murabba'1 }\end{array}$} & $\begin{array}{l}\text { Silmeli kenarı lambalı döşeme inşası } \\
\text { Silmeli ve şemsiyeli tavan inşası }\end{array}$ & 20 & \\
\hline & Alet ve edevat mesarifiyle müteahhid karı & 4,00 & \\
\hline & Yekün & & 24,00 \\
\hline & Ma müştemilat bir metro murabba'1 kapı inşası & 15,00 & \\
\hline & $\begin{array}{l}\text { Ma müştemilat bir metro murabba'1 pencere çerçevesi } \\
\text { inşası }\end{array}$ & 10,00 & \\
\hline
\end{tabular}



Fig. 2. Keşif Defteri Kapak Sayfası (BOA. DH. EUM. MH. 245/24-3) 


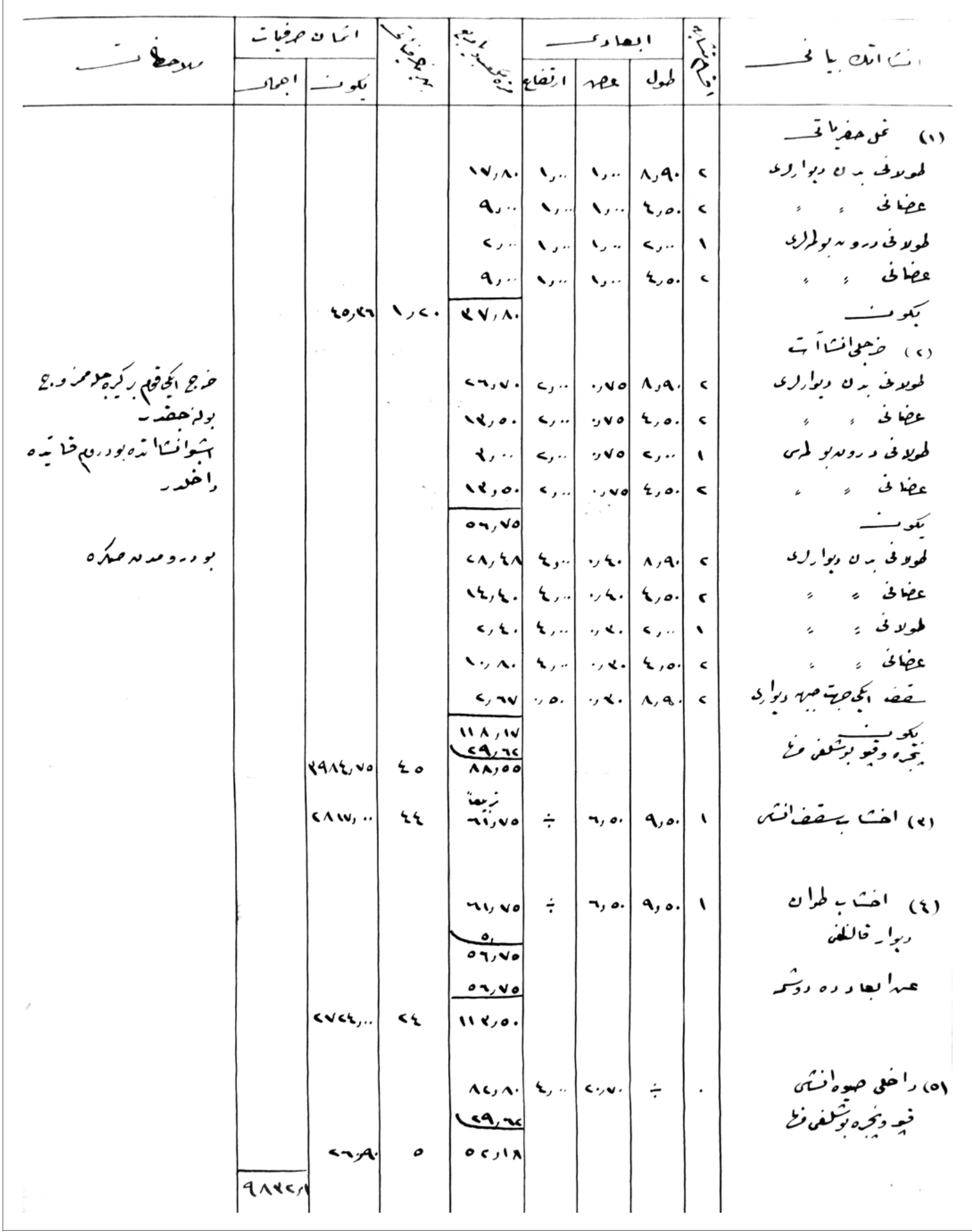

Fig. 3. Keşif Defteri Birinci Sayfası (BOA. DH. EUM. MH. 245/24-3) 


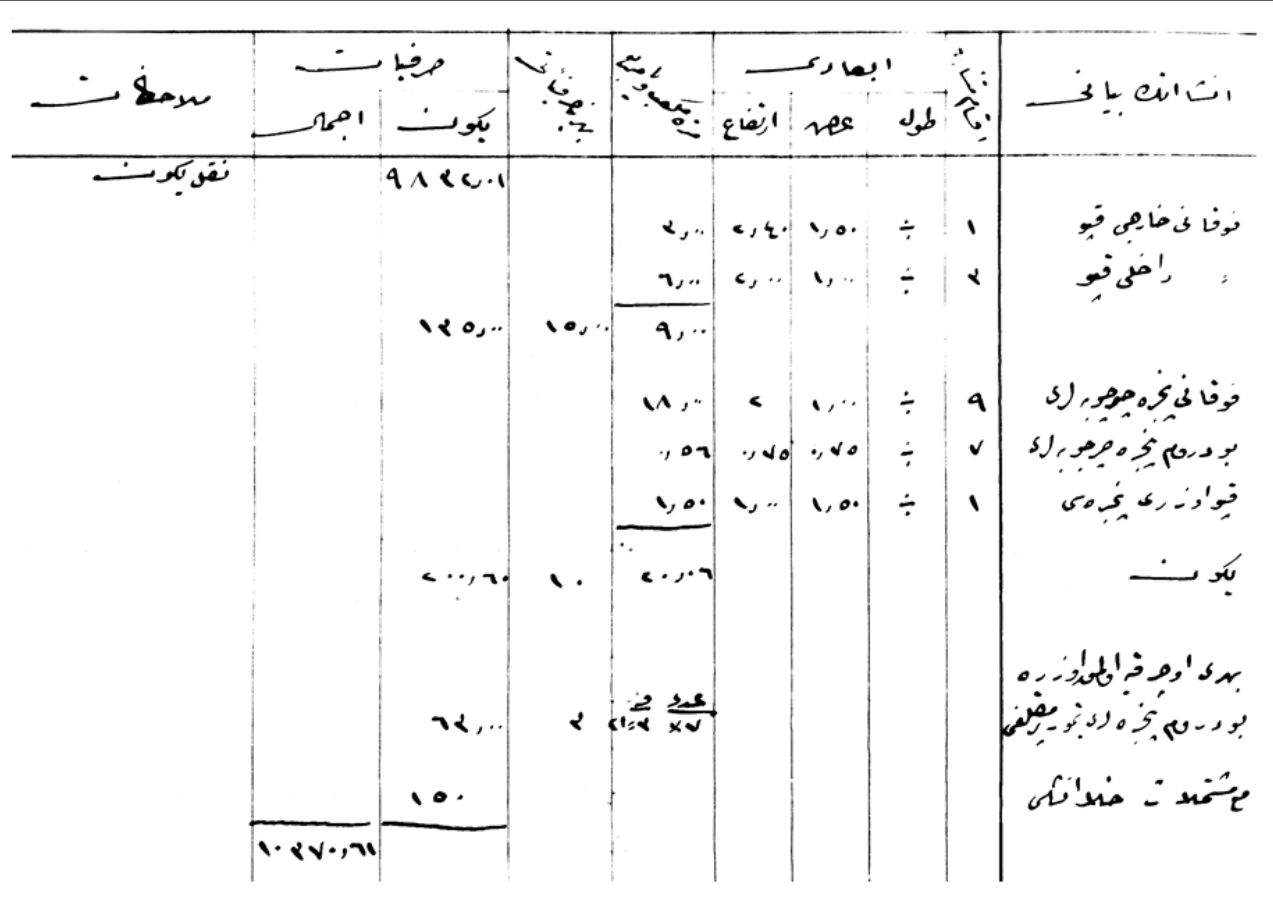

Fig. 4. Keşif Defteri İkinci Sayfası (BOA. DH. EUM. MH. 245/24-3)

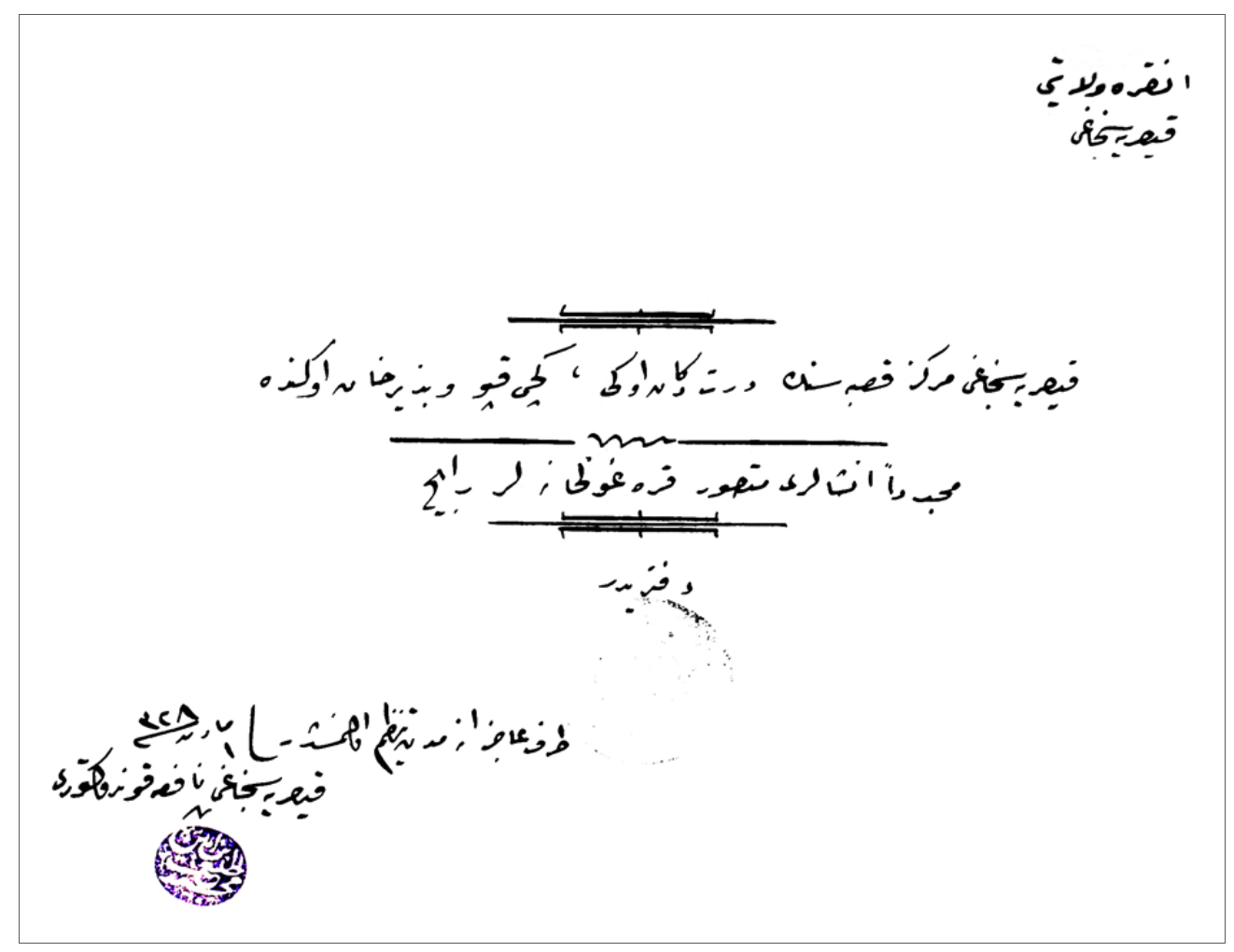

Fig. 5. Rayiç Defteri Kapak Sayfası (BOA. DH. EUM. MH. 245/24-3) 


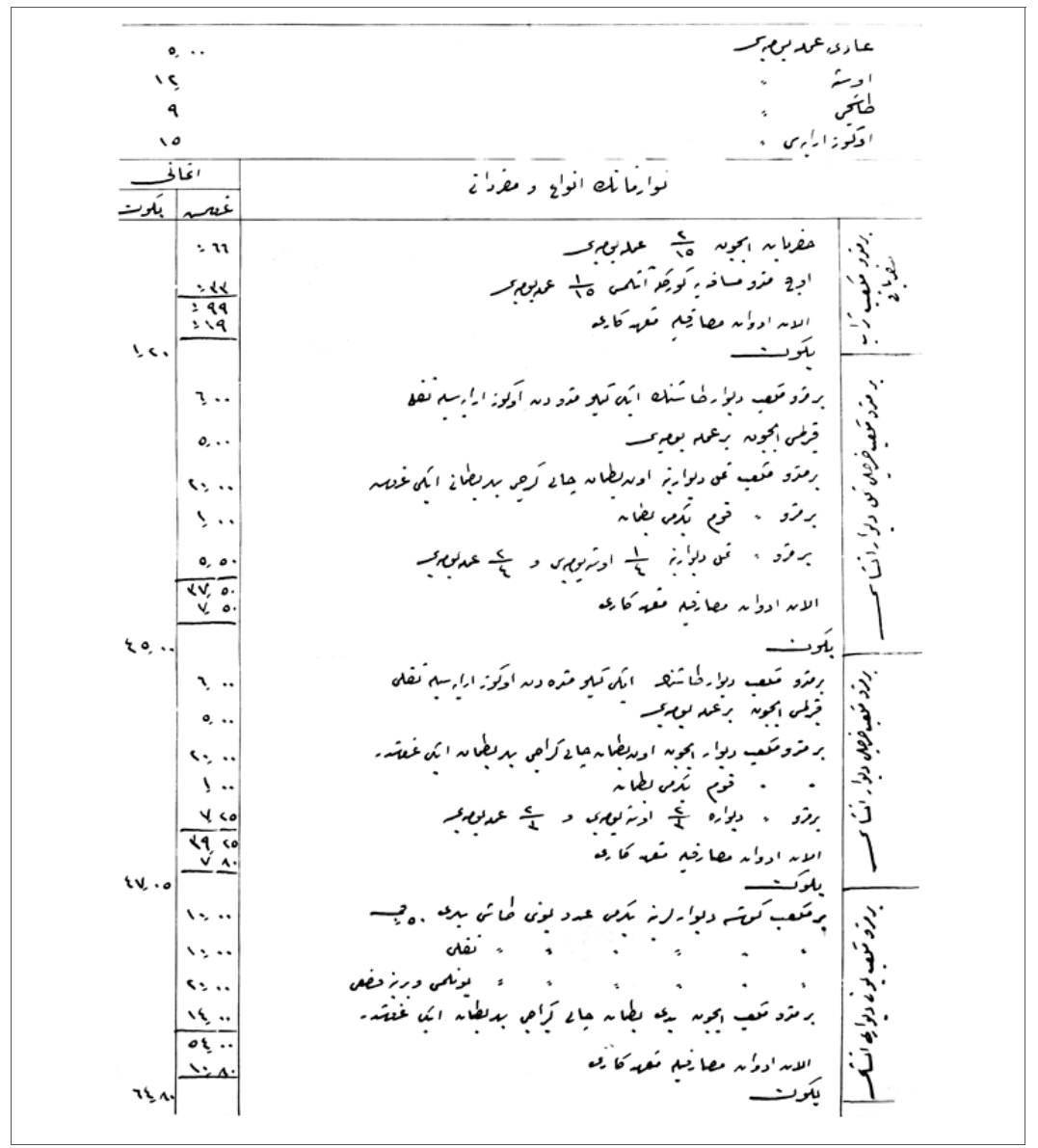

Fig. 6. Rayiç Defteri Birinci Sayfası (BOA. DH. EUM. MH. 245/24-3)

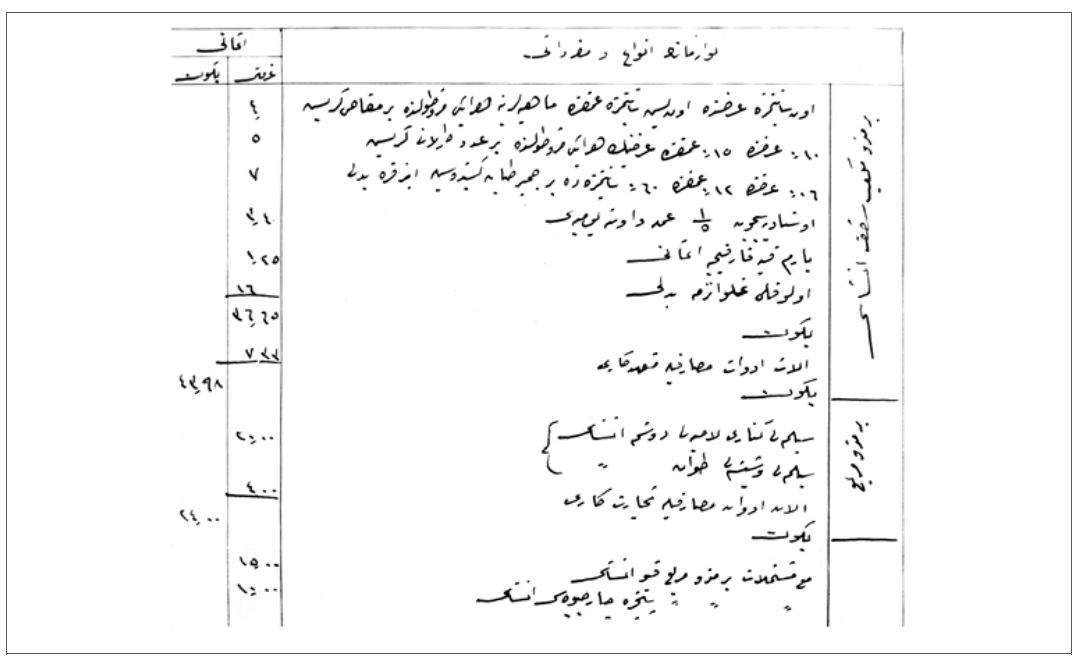

Fig. 7. Rayiç Defteri İkinci Sayfası (BOA. DH. EUM. MH. 245/24-3) 


\section{KAYNAKÇA}

Alyot H. T. (1947). Türkiye'de Zabita (Tarihi Gelişim ve Bugünkü Durum). Ankara 1947.

Arslan N. (1999). "II. Mahmud ve Abdülmecid Dönemi Karakol Binaları". Uluslararası Dördüncü Türk Kültürü Kongresi Bildirileri (4-7 Kasım 1997). Cilt 1 (1999) 69-84.

Bilgiç V. K. \& Karakaya M. (2002). "Türk Polis Teşkilatının Gelişimi”. Polis Bilimleri Dergisi 4/1-2 (2002) 171-186.

Birinci A. (1999). “Türk Emniyet Teşkilatında İlkler”. Polis Bilimleri Dergisi 1/3 (1999) 9-16.

Çadırcı M. (2013). Tanzimat Döneminde Anadolu Kentlerinin Sosyal ve Ekonomik Yapısı. Ankara 2013.

Çiftçi A. (1996). Son Dönem İstanbul Karakolları Anadolu Yakası ve Büyükdere Topçu Karakolu. Yayımlanmamış Yüksek Lisans Tezi. Yıldız Teknik Üniversitesi, İstanbul 1996.

Çiftçi A. (1998). "Eyüp Sultan'ın Tarihi Karakolları". Tarihi, Kültürü ve Sanattyla II. Eyüp Sultan Seтроzуити Tebliğler (8-10 Mayls 1998). (1998) 226-237.

Çiftçi A. (2001). "Karakol Binaları". Türkiye Diyanet Vakfi İslam Ansiklopedisi (Cilt 24) 431-434. İstanbul 2001.

Doğan A. (1994). "Polis Okulları". Dünden Bugüne İstanbul Ansiklopedisi (Cilt 6) 277-278. İstanbul 1994.

Eravşar O. (2013). "Haritalar”. Kayseri Ansiklopedisi (Cilt 3) 112-117. İstanbul 2013.

Ergin O. N. (1995). Mecelle-i Umur-ı Belediye. Cilt 2. Yay. Yön. Cengiz Özdemir. İstanbul 1995.

Ertuğrul A. (2009). "XIX. Yüzyılda Osmanlı'da Ortaya Çıkan Farklı Yapı Tipleri”. Türkiye Araştırmaları Literatür Dergisi 13/ 7 (2009) 293-312.

Fındıklı R. (1999). “Osmanlı Devleti’nde Güvenlik ve Polis”. Eds. Kemal Çiçek \& Cem Oğuz. Osmanlı Cilt 6 (1999) 295-300.

Hasol D. (1979). Ansiklopedik Mimarlık Sözlüğ̈̈. İstanbul 1979.

Kaynar S. (2002). Tarihi Süreç İçerisinde Türk Polis Teşkilatı'nın Kuruluşu. Yayımlanmamış Yüksek Lisans Tezi. Niğde Üniversitesi, Niğde 2002.

Lévy N. (2006). "Polislikle İlgili Bilgilerin Dolaşım Tarzları: Osmanlı Polisi İçin Fransız Modeli mi?". Eds. Noémi Levy, Nadir Özbek \& Alexandre Toumarkine. Jandarma ve Polis Fransız ve Osmanlı Tarihçiliğine Çapraz Bakışlar (2006) 146-170.

Okçabol D. (1940). Türk Zabıta Tarihi ve Teşkilat Tarihçesi. Ankara 1940.

Özbek Y. (2011). Kayseri'de Tarihi Okul Yapıları. Kayseri 2011.

Özcan A. (2001). "Karakol”. Türkiye Diyanet Vakfi İslam Ansiklopedisi (Cilt 24) 430-431. İstanbul 2001.

Özcan A. (2002). "Osmanlı İstanbul'unda Kolluk Hizmetleri ve Modern Anlamda İlk Karakol Teşkilatının Kurulması". XIII. Türk Tarih Kongresi Ankara, 4-8 Ekim 1999 Kongreye Sunulan Bildiriler. Cilt 3/3 (2002) 1753-1760.

Pakalın M. Z. (1983). Osmanlı Tarih Deyimleri ve Terimleri Sözlüğ̈̈. Cilt 2. İstanbul 1983.

Sevin N. A. (2002). "XIX. Yüzyıl Osmanlı Başkentinde Polis Teşkilatı ve Karakol Binaları". Eds. Hasan Celal Güzel, Kemal Çiçek \& Salim Koca. Türkler Ansiklopedisi (Cilt 15) 395-399. Ankara 2002.

Sami Ş. (2009) Kâmûs-ı Türkî. İstanbul 2009.

Tanışık G. (2009). Emniyet-i Umumiye Müdüriyeti Kayıtlarına Göre Polis Teşkilatı Kadro Hareketleri (1909-1938). Yayımlanmamış Yüksek Lisans Tezi. Ondokuz Mayıs Üniversitesi, Samsun 2009.

Tongur H. (1946). Türkiye'de Genel Kolluk Teşkil ve Görevlerinin Gelişimi. Ankara 1946.

Tongur H. (1948). Türkiye'de Illk Zaptiyeler. Ankara 1948.

Toprak Z. (1986). “Tanzimat'tan Sonra Osmanlı Kolluk Kuvvetleri”. Tanzimat'tan Cumhuriyet'e Türkiye Ansiklopedisi (Cilt V) 1269-1271. İstanbul 1986.

Toprak Z. (1994). "Güvenlik Hizmetleri”. Dünden Bugüne İstanbul Ansiklopedisi (Cilt 3) 457-459. İstanbul 1994.

Yaşar Y. (2008). Açıklamalı Polis Meslek Hukuku. Ankara 2008.

Yavaş D. (2003). "Bursa'da Osmanlı Dönemi Karakolhaneleri”. Uludağ Üniversitesi, Fen-Edebiyat Fakültesi Sosyal Bilimler Dergisi 5 (2003) 71-79. 


\section{Başbakanlık Osmanlı Arşivi Vesikaları (BOA)}

BOA. Bab-1 Ali Evrak Odas1, (BEO.) 2370/177713-1, 2, 3, 4.

BOA., Dahiliye, Emniyet-i Umumiye, (DH. EUM.) 60/10-1, 2.

BOA., Dâhiliye, Emniyet-i Umumiye, Memurin Kalemi, (DH. EUM. MEM.) 123/48-1, 2.

BOA., Dâhiliye, Emniyet-i Umumiye, Muhasebe Kalemi, (DH. EUM. MH.) 76/55-1, 3; 88/83-1; 111/95; 138/116-1, 2, 3; 147/7; 152/52-1, 2; 167/9-1, 2; 244/57; 245/24-1, 1a, 2, 3, 4; 259/13.

BOA., Dâhiliye, İrade-i Umumiye, (DH. İ. UM.) 20/2.

BOA., Dâhiliye, Mektubi Kalemi, (DH. MKT.) 229/58-2; 1747/92.

BOA., Meclis-i Vala, (MV.) 109/81.

\section{Yazarın Notu}

Çalışmada kullanılan belgelerin büyük bir kısmı 2010 yılında tarafımızdan tespit ve temin edilmişti. Ancak zaman içerisinde konu ile ilgili yeni belgeler, arşiv tasniflerinde yerini aldı. Tasnife yeni giren belgelerin temini hususunda yardımlarını esirgemeyen öğrencilerim Burcu TİLBE ve Herdem ÜNAL'a teşekkür ederim. Elle yaptığımız restitüsyon çizimlerini Autocad programına aktaran ve çeşitli gerekçelerle temin edemediğimiz bir kısım belgeyi, arşivden temin eden öğrencim Arş. Gör. Zeynep AYTEKİN ile dijital görüntüleri dergi yayın kurulunun istediği nitelikte, yayıma hazır hale getiren Grafiker Öğr. Gör. Ömer OKUR'a şükranlarımı sunarım. 